\title{
Anti-Pathogenic Functions of Non-Digestible Oligosaccharides In Vitro
}

\author{
Mostafa Asadpoor ${ }^{1,+}$, Casper Peeters ${ }^{1,+}$, Paul A. J. Henricks ${ }^{1}{ }^{(\mathbb{C}}$, Soheil Varasteh ${ }^{1}$, \\ Roland J. Pieters ${ }^{2}$ (D) Gert Folkerts ${ }^{1}$ and Saskia Braber ${ }^{1, *}$ \\ 1 Division of Pharmacology, Utrecht Institute for Pharmaceutical Sciences, Faculty of Science, \\ Utrecht University, Universiteitsweg 99, 3584 CG Utrecht, The Netherlands; m.asadpoor@uu.nl (M.A.); \\ Casper.peeters@live.nl (C.P.); P.A.J.Henricks@uu.nl (P.A.J.H.); soheil.varasteh@gmail.com (S.V.); \\ g.folkerts@uu.nl (G.F.) \\ 2 Division of Medicinal Chemistry and Chemical Biology, Utrecht Institute for Pharmaceutical Sciences, \\ Faculty of Science, Utrecht University, Universiteitsweg 99, 3584 CG Utrecht, The Netherlands; \\ R.J.Pieters@uu.nl \\ * Correspondence: S.Braber@uu.nl; Tel.: +31-(0)30-253-7353; Fax: +31-(0)30-253-7900 \\ + These authors contributed equally to this work.
}

Received: 11 May 2020; Accepted: 12 June 2020; Published: 16 June 2020

Abstract: Non-digestible oligosaccharides (NDOs), complex carbohydrates that resist hydrolysis by salivary and intestinal digestive enzymes, fulfill a diversity of important biological roles. A lot of NDOs are known for their prebiotic properties by stimulating beneficial bacteria in the intestinal microbiota. Human milk oligosaccharides (HMOs) represent the first prebiotics that humans encounter in life. Inspired by these HMO structures, chemically-produced NDO structures (e.g., galacto-oligosaccharides and chito-oligosaccharides) have been recognized as valuable food additives and exert promising health effects. Besides their apparent ability to stimulate beneficial microbial species, oligosaccharides have shown to be important inhibitors of the development of pathogenic infections. Depending on the type and structural characteristics, oligosaccharides can exert a number of anti-pathogenic effects. The most described effect is their ability to act as a decoy receptor, thereby inhibiting adhesion of pathogens. Other ways of pathogenic inhibition, such as interference with pathogenic cell membrane and biofilm integrity and DNA transcription, are less investigated, but could be equally impactful. In this review, a comprehensive overview of In vitro anti-pathogenic properties of different NDOs and associated pathways are discussed. A framework is created categorizing all anti-pathogenic effects and providing insight into structural necessities for an oligosaccharide to exert one of these effects.

Keywords: non-digestible oligosaccharides; bacteria; bacterial growth; biofilm; adhesion; surface charge; chemical structure; HMOs; in vitro

\section{Introduction}

In recent years, there has been a growing interest in functional foods/nutraceuticals that have the ability to enhance human health, resulting in one of the leading trends in today's food industry. Dietary carbohydrates, especially non-digestible oligosaccharides (NDOs), have been introduced as functional food ingredients. NDOs are known to selectively promote the growth and/or activity of beneficial bacteria in the gut, especially Lactobacilli and Bifidobacteria and, therefore, recognized as prebiotics [1]. To reach and be effective in the large intestine, NDOs are resistant to hydrolysis by intestinal digestive enzymes in the upper part of the intestines.

There is a great body of evidence that health-promoting effects of NDOs are not limited to shaping the intestinal microbiota and the microbiota-associated immune responses, but also include 
microbiota-independent effects on epithelial and immune cells [2]. It has been described that supplementation of NDOs to the diet in early life can decrease the development of diseases, such as allergies [3]. However, NDOs can also induce therapeutic effects in different inflammatory diseases later in life, including colitis, lung emphysema, cancer and HIV [4]. Recently, there has been particular scientific interest in the anti-pathogenic properties of NDOs for treatment (or prevention) of several kinds of infections, including gastrointestinal and respiratory infections [5,6]. Especially, antibiotic-resistant bacteria pose a great threat to human health and are associated with a major cause of morbidity and mortality worldwide [7]. Adhesion to host proteins (saccharides patterns) and biofilm development are thought to be two important pathogenic mechanisms. Bacterial biofilm formation is associated with a wide range of infections and reduces pathogenic susceptibility to antibiotic treatment. The multicellular nature of biofilms prevents the penetration of antimicrobial agents. Aggravation of antibiotic resistance among pathogenic species has urged development of alternative treatments for infections [8].

The microbiota protect against infections by promoting beneficial bacteria, such as Bifidobacterium and Lactobacillus, by inhibiting pathogenic bacteria or by orchestrating appropriate immune responses, therefore NDOs can play an important role in treating infections [9]. This topic has been extensively reviewed in recent publications [10-12].

NDOs can also act as anti-adhesives to selectively prevent adhesion of certain pathogen species to human cells and to mucin. For their adhesion-inhibiting properties, NDOs rely on structural similarity with oligosaccharide patterns presented on proteins on the host cell surface [13]. These patterns are essential for fimbria/pili-mediated pathogenic adhesion, allowing for anti-pathogenic capability termed receptor-mimicry [14-16]. In addition, it has been reported that NDOs possess anti-biofilm activity against different pathogenic microbes. NDOs can inhibit the development of pathogenic infection of the intestine before pathogen adhesion $[14,17,18]$ or during one of the initial stages of biofilm formation [19-21] through direct interaction with pathogens.

Human milk contains a large amount of structurally diverse oligosaccharides, termed human milk oligosaccharides (HMOs), which represent the first prebiotics that humans encounter in life. Each structurally defined HMO might have a distinct functionality related to their anti-pathogenic properties. Inspired by the prebiotic and anti-pathogenic potential of HMOs, similar oligosaccharide structures were tested for their anti-pathogenic capability [14]. Some of the oligosaccharides produced are based on monosaccharides also present in HMOs, such as galactose (Gal) in galacto-oligosaccharides (GOS) and N-acetylglucosamine (GlcNAc) in chito-oligosaccharides (COS). Other commercial oligosaccharides with anti-pathogenic potential include mannan-oligosaccharides (MOS), alginate oligosaccharide (AOS), pectic oligosaccharides (POS) and fructo-oligosaccharides (FOS). These commercial NDOs can be obtained by direct extraction from natural sources or produced via enzymatic or chemical synthesis from saccharides [22]. There is a high structural diversity amongst these NDOs and depending on their key characteristics, such as monosaccharide components, charge, degree of polymerization (DP) and degree of acetylation (DA), these oligosaccharides elicit anti-pathogenic effects in a variety of ways.

In this review, an extensive overview of the anti-pathogenic effects of different NDOs and their postulated mechanisms are addressed. Herein, the focus lies on direct interaction of oligosaccharides with pathogens or components of the biofilm. Since the NDO-induced effects on the microbiota and microbiota-generated metabolites cannot be neglected in vivo, only In vitro studies are included. A framework is created categorizing all anti-pathogenic effects of relevant NDOs and providing insight into the structural requirements for an oligosaccharide to exert one of these effects. 


\section{Human Milk Oligosaccharides}

\subsection{Structure}

HMOs are soluble complex and diverse sugars containing Gal, Glc, fucose (Fuc), N-acetylglucosamine (GlcNAc), or sialic acid (Neu5Ac) monosaccharides. In the mammary glands, the HMOs are biosynthesized with the formation of a lactose core from Glc and Gal catalyzed by $\beta$-galactotransferase in the presence of $\alpha$-lactalbumin. Galactose can be elongated enzymatically by $\beta 1-4$ linkage to $\mathrm{N}$-acetyllactosamine or by $\beta 1-3$ linkage to lacto-N-biose. The core HMO structure can be further elongated by the addition of $\mathrm{N}$-acetyllactosamine and lacto-N-biose units by $\beta 1-6$ and $\beta 1-3$ linkages; Fuc connected with $\alpha 1-3, \alpha 1-2$, or $\alpha 1-4$ linkages; and/or sialic acid residues attached by $\alpha 2-6$ or $\alpha 2-3$ linkages at the terminal positions (Figure 1) [23]. Human milk contains three major HMO types: neutral (Fucosylated) HMOs (e.g., 2-fucosyllactose (2-FL)), neutral N-containing HMOs (lacto-N-tetraose (LNT)) and acidic (sialylated) HMOs (e.g., 3-sialyllactose (3-SL)) [24].

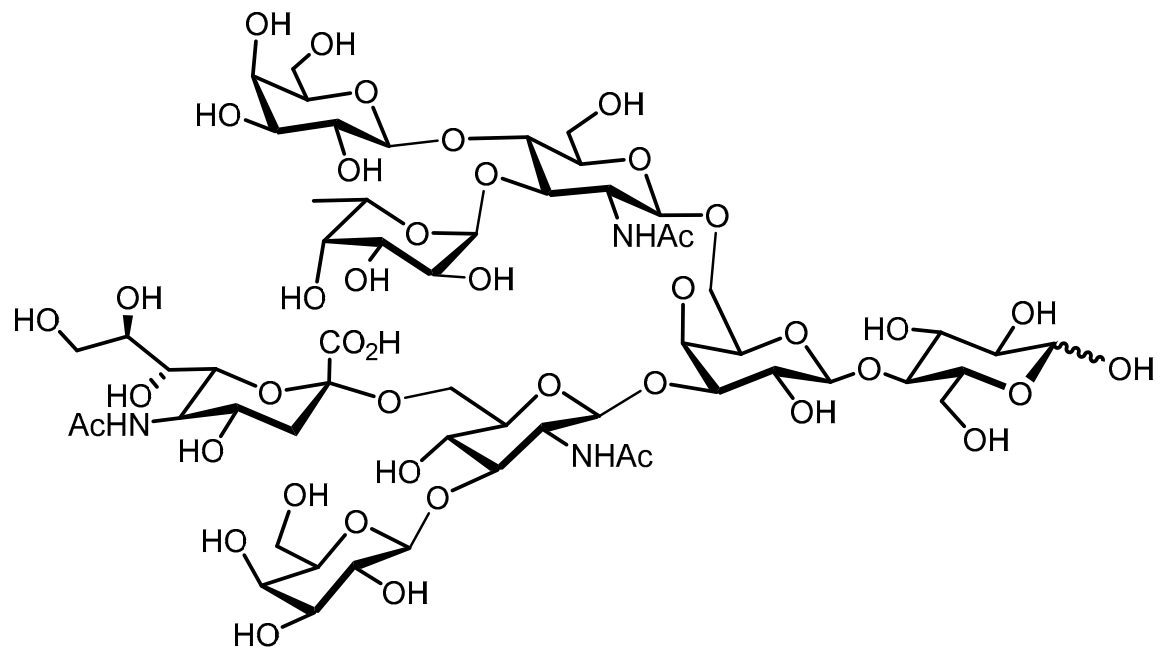

Figure 1. Exemplary structure of an HMO.

\subsection{Anti-Pathogenic Functionalities HMO Mixtures}

HMOs have been shown to interact with pathogenic bacteria in a variety of ways (Table 1). Depending on their structural characteristics, HMOs may interact with adhesion factors on the pathogenic surface, or penetrate and interact with elements of the pathogenic biofilm, inhibiting microbial adhesion and biofilm growth $[25,26]$. When pathogens bind specific HMOs that resemble saccharide structures on the epithelial cell surface, their capacity to adhere to epithelial cells is inhibited.

\subsubsection{Anti-Adhesion HMO Mixtures}

HMO structures binding to pathogenic fimbriae by resembling patterns on epithelial cell surface receptors are called decoy receptors [25]. The ability of HMOs to influence pathogenic adhesion is influenced by a number of variables, such as the percentage of fucosylated or acidic oligosaccharides in the mixture (the fucosylated and sialylated fraction, respectively), oligosaccharide weight or the type of pathogen.

\section{Neutral HMO Fraction-Fucosylated and Non-Fucosylated}

Neutral HMO fractions are known to inhibit adhesion of pathogens to epithelial cells. As a whole, the neutral fraction of HMOs inhibits an Escherichia coli strain, which is specifically P-fimbriated. i.e., galabiose (or galactose) specific, indicating a mechanism of receptor-mimicry [27]. After separation of a neutral oligosaccharide mixture into a high-and low-molecular weight fraction (HMWF and LMWF, respectively), the two fractions showed varying adhesion-inhibiting potential depending on 
the pathogen strain. The HMWF showed inhibition of Vibrio cholerae adhesion, whereas the LMWF inhibited Salmonella fyris [17], which contrasts the finding that the LMWF more potently inhibits Vibrio cholerae adhesion [28]. Larger HMOs appear to have an advantage over smaller HMOs in inhibiting the adhesion of pulmonary infectious strains, such as Haemophilus influenzae, however, the effect is also dependent on the composition of the HMO mixture [29]. One factor affecting pathogen adhesion to epithelial cells is the fucosylation status of the HMO mixture. Oligosaccharides are fucosylated by FUT2 ( $\alpha 1,2$-fucose) or FUT3 ( $\alpha 1,4$-fucose) [25]. In general, $\alpha 1,2$-fucose patterns on epithelial cell exterior have been shown to protect epithelial cells from pathogenic infection by facilitating colonization of a layer of probiotic microbes [30,31]. In addition, locally secreted glycan molecules may inhibit pathogenic colonization through a decoy-receptor mechanism, although this mechanism has not been fully elucidated [31,32].

In accordance with anti-colonization functionalities exerted by native fucosyl-containing elements, $\alpha 1,2-$ fucosylated HMOs have also shown to exert anti-adhesion effects. A large part of the neutral oligosaccharide fraction is made up of fucosylated oligosaccharides, which is usually present at the reducing end of the oligosaccharide sequence [33]. Small fucosylated HMOs inhibit enteropathogenic Escherichia coli (EPEC) adhesion, when added to a HEP-2 monolayer along with EPEC [34], while fucosylated oligosaccharides show superior adhesion inhibition of Neisseria meningitidis to salivary agglutinin [35]. Although these results point in the direction of receptor mimicry functionalities of the neutral fraction, the anti-pathogenic effect cannot be tracked to a specific saccharide structure as the molecular diversity in these mixtures is very high [36]. Testing of isolated HMOs gives a better indication of the inhibitory capacities compared to testing of HMOs in mixture, this is discussed in the Isolated HMO structures section.

\section{Acidic HMO Fraction}

The acidic fraction of HMOs consists of sialylated oligosaccharides, which are negatively charged at homeostatic $\mathrm{pH}$. Sialylated HMOs are produced by the action of sialyltransferase enzymes resulting in $\alpha 2,3$ and $\alpha 2,6$-sialylated oligosaccharides [25]. Due to the charge residing on the sialylated oligosaccharides, and their consequent interaction with oppositely charged elements on the epithelial cell exterior, their adhesion-inhibiting effect is less dependent on pathogen type compared to the neutral fraction [17]. Similar to neutral HMO fractions, the acidic HMO fraction shows inhibitory potential towards pathogenic species expressing specific fimbrial types, such as P and CFA fimbriae-expressing Escherichia coli. The lack of inhibition of HMO's for P-fimbriated Escherichia coli is clarified by the lack of affinity of the P-fimbrial lectin for sialylated oligosaccharides instead of the Gal $\alpha 1,4$ Gal (galabiose) termini on the cell surface, which are involved in recognition and adhesion of P-fimbriated pathogen species [27].

\subsubsection{Other Anti-Pathogenic Mechanisms of HMO Mixtures}

Group B Streptococcus (GBS), often associated with post-natal infection and mortality, and its interaction with different HMOs has been of significant scientific interest in recent years. Pooled HMOs were shown to inhibit GBS growth and biofilm formation, provoking an alteration in biofilm structure. A suggested reason for the antibiofilm activity of these oligosaccharides is interference with nutrient cross-membrane transport by adhesion to the pathogen exterior [21].

Additionally, pooled HMOs potentiated the bactericidal function of a select number of ribosome-targeting antibiotics, clindamycin and erythromycin especially, against antibiotic resistant GBS and Acinetobacter baumannii, without the protection of a biofilm [37]. It was hypothesized that this is due to increased permeability of pathogens, a mechanism potentiated by polymyxins [38]. Antibiotics inhibiting cell wall synthesis are not potentiated, while treating any pathogenic strain in combination with pooled HMOs.

Finally, pathogenic cellular invasion can be affected by the presence of an HMO mixture. Pooled HMOs can inhibit Escherichia coli invasion of epithelial bladder cells by over $80 \%$. Reportedly, 
HMOs aid in the preservation of paxillin [39], which is associated with the promotion of cohesion of the epithelial cell monolayer as a focal adhesion molecule [40]. The cell-protecting effect is further substantiated by complete inhibition of UPEC-induced upregulation of MAPK signalling [39], an important apoptotic cascade. Wider employment of this anti-pathogenic effect requires additional research with a higher variety of cell lines and experimental set ups.

Table 1. Overview of the anti-pathogenic functionalities of HMO mixtures.

\begin{tabular}{|c|c|c|c|c|}
\hline $\begin{array}{l}\text { HMO Characteristics } \\
\text { (Source) }\end{array}$ & [HMO] & Strains Used & Observed Effects & References \\
\hline $\begin{array}{l}\text { Breast milk collected from } \\
\text { first and fourth week of } \\
\text { lactation }\end{array}$ & 1:2 dilution & $\begin{array}{c}\text { Gram-positive: } \\
\text { Streptococcus } \\
\text { pneumoniae } \\
\text { Gram-negative: } \\
\text { Haemophilus influenzae }\end{array}$ & $\begin{array}{l}\text { Anti-adhesive effects against } \\
\text { Haemophilus influenzae } \\
\text { (HMWF) and Streptococcus } \\
\text { pneumoniae (all HMOs) }\end{array}$ & [23] \\
\hline $\begin{array}{l}\text { Breast milk from healthy } \\
\text { women collected } 30 \text { days } \\
\text { after delivery }\end{array}$ & $6 \mathrm{mg} / \mathrm{mL}$ & $\begin{array}{l}\text { Gram-negative: } \\
\text { UPEC }\end{array}$ & $\begin{array}{c}\text { Anti-adhesive effects of } \\
\text { neutral fractions (high > low } \\
\text { Mw) }\end{array}$ & [28] \\
\hline $\begin{array}{l}\text { Colostrum }(\mathrm{d} 1-4), \\
\text { transitional }(\mathrm{d} 12-17) \text { and } \\
\text { mature }(\mathrm{d} 28-32) \text { breast milk } \\
\text { from healthy women }\end{array}$ & $\begin{array}{l}25-1200 \mu \mathrm{g} / \\
\text { well }(50 \mu \mathrm{L})\end{array}$ & $\begin{array}{l}\text { Gram-negative: } \\
\text { ETEC (CFA/I, CFA/II } \\
\text { fimbriae), UPEC (P, } \\
\text { P-like fimbriae) }\end{array}$ & $\begin{array}{c}\text { Inhibition of } \\
\text { hemagglutination by } \\
\text { desialylated fraction } \\
\text { associated with binding to } \\
\text { P-fimbriae }\end{array}$ & [27] \\
\hline $\begin{array}{l}\text { Pooled transitional breast } \\
\text { milk samples }\end{array}$ & $20 \mathrm{~g} / \mathrm{L}$ & $\begin{array}{c}\text { Gram-negative: } \\
\text { Neisseria meningitidis }\end{array}$ & $\begin{array}{l}\text { Inhibition of binding to pili } \\
\text { by acidic HMO fraction }\end{array}$ & [35] \\
\hline $\begin{array}{l}\text { HMO fractions and } \\
\text { modified HMO fractions } \\
\text { from pooled human milk }\end{array}$ & $1-2 \mathrm{~g} / \mathrm{L}$ & $\begin{array}{l}\text { Isolated, immobilized } \\
\text { P-selectin }\end{array}$ & $\begin{array}{l}\text { Interference acidic HMO } \\
\text { fraction and P-selectin. } \\
\text { Neutral HMOs show no } \\
\text { interference. }\end{array}$ & [41] \\
\hline $\begin{array}{l}\text { Colostrum (different } \\
\text { fractions) collected four days } \\
\text { after delivery }\end{array}$ & $\begin{array}{l}\text { 1, } 5 \text {, and } 10 \\
\mathrm{mg} / \mathrm{mL}\end{array}$ & $\begin{array}{l}\text { Gram-negative: } \\
\text { EPEC, Vibrio cholerae, } \\
\text { Salmonella fyris }\end{array}$ & $\begin{array}{l}\text { Anti-adhesive effects against } \\
\text { Salmonella fyris (acidic, } \\
\text { neutral, LMw), and Vibrio } \\
\text { cholerae (neutral, hMw) }\end{array}$ & [17] \\
\hline $\begin{array}{l}\text { HMOs isolated from pooled } \\
\text { human milk }\end{array}$ & $15 \mathrm{mg} / \mathrm{mL}$ & $\begin{array}{l}\text { Gram-negative: } \\
\text { UPEC }\end{array}$ & $\begin{array}{l}\text { Inhibition of bacterial } \\
\text { invasion but no } \\
\text { anti-adhesive effects, } \\
\text { protection }\end{array}$ & [39] \\
\hline $\begin{array}{l}\text { Breast milk from healthy } \\
\text { women collected between } 3 \\
\text { days and } 3 \text { months postnatal }\end{array}$ & $5 \mathrm{mg} / \mathrm{mL}$ & $\begin{array}{l}\text { Gram-positive: } \\
\text { GBS }\end{array}$ & Up to $40 \%$ growth inhibition & [21] \\
\hline $\begin{array}{l}\text { Breast milk from healthy } \\
\text { women collected between } 3 \\
\text { days and } 3 \text { months postnatal }\end{array}$ & $5 \mathrm{mg} / \mathrm{mL}$ & $\begin{array}{c}\text { Gram-positive: } \\
\text { GBS (CNCTC, GB590, } \\
\text { GB2) }\end{array}$ & $\begin{array}{c}8-32 \times \text { MIC reduction with } \\
\text { antibiotics in combination } \\
\text { with HMOs }\end{array}$ & [42] \\
\hline $\begin{array}{l}\text { Breast milk from healthy } \\
\text { women collected between } 3 \\
\text { days and } 3 \text { months postnatal }\end{array}$ & $5 \mathrm{mg} / \mathrm{mL}$ & $\begin{array}{c}\text { Gram-positive: } \\
\text { GBS, Staphylococcus } \\
\text { aureus } \\
\text { Gram-negative: } \\
\text { Acinetobacter baumannii }\end{array}$ & $\begin{array}{l}\text { GBS and Staphylococcus } \\
\text { aureus biofilm inhibition, no } \\
\text { antimicrobial effect }\end{array}$ & [43] \\
\hline $\begin{array}{l}\text { Breast milk from healthy } \\
\text { women collected between } 3 \\
\text { days and } 3 \text { months postnatal }\end{array}$ & $5 \mathrm{mg} / \mathrm{mL}$ & $\begin{array}{l}\text { Gram-negative: } \\
\text { GBS (GB590, GB2) }\end{array}$ & $\begin{array}{l}\text { HMO mixture more effective } \\
\text { inhibition of pathogen } \\
\text { growth and viability } \\
\text { reduction than isolated } \\
\text { oligosaccharides }\end{array}$ & [44] \\
\hline
\end{tabular}

\subsection{Anti-Pathogenic Functionalities Isolated HMO Structures}

The apparent antimicrobial functionalities of HMOs encouraged investigation of a number of isolated HMO structures. Even though the HMO mixture consists of over 100 distinct structures [45], the pathogenic interactions of only a relatively small number of individual HMO structures have been investigated (Table 2). 


\subsubsection{Neutral Isolated HMO Structures}

An example of an isolated HMO widely studied for its interactions with pathogens is 2-fucosyl-lactose (2-FL). 2-FL $(\alpha-\mathrm{L}-\mathrm{Fuc}-(1 \rightarrow 2)-\beta-\mathrm{D}-\mathrm{Gal}-(1 \rightarrow 4)-\mathrm{D}-\mathrm{Glc}$ or, $\alpha-\mathrm{L}-\mathrm{fucopyranosyl-}$ $(1 \rightarrow 2)-\beta-\mathrm{D}-$ galacto-pyranosyl- $(1 \rightarrow 4)-\mathrm{D}-$ glucopyranoside) is the most abundant fucosylated HMO in breast milk and has in multiple instances been linked with anti-adhesive properties. 2-FL mimics the H-2 epitope on epithelial cells. This glycosylic structure is important to pathogenic adhesion to epithelial cells [36]. Through this mechanism, 2-FL was shown to inhibit the adhesion of Campylobacter jejuni [46], Pseudomonas aeruginosa, EPEC, Salmonella enterica [47], but not the adhesion of UPEC, Vibrio cholerae and Salmonella fyris [17]. Even though specificity of certain pathogens for the H-2 epitope has been confirmed [48], the biochemical origin of pathogenic affinity for 2-FL was not further elucidated.

Although anti-adhesion functionalities of 2-FL have been well-described, there is scarce information about other types of anti-pathogenic effects of 2-FL. For interaction with pathogens in a biofilm structure, it is suggested that the neutral state of 2-FL limits it from entering the biofilm; attachment of a cationic element to 2-FL enables the molecule to enter extracellular polymeric substances (EPS) structures and exert antibiofilm activity [49].

3-Fucosyllactose (3-FL) is another trisaccharide observed in human milk, which is different in structure from 2-FL as its assimilation involves the enzymatic function of 3-fucosyltransferase (attachment of fucose to the reducing Glc end) instead of 2-fucosyltransferase [25]. Like 2-FL, interaction with pathogens has been documented for 3-FL in a number of instances [17], though the concentration of 3-FL $(0.44 \mathrm{~g} / \mathrm{L})$ is lower in human milk samples compared to 2-FL (2.74 g/L) [50]. 3-FL inhibits adhesion to a number of pathogens, including UPEC, Salmonella fyris [17], EPEC, Campylobacter jejuni, Salmonella enterica and Pseudomonas aeruginosa [47]. Inhibition of adhesion of UPEC and Salmonella fyris by 3-FL, but not by 2-FL, indicates the importance of the location of fucosylation, apparently influencing the pathogenic receptor binding to the HMO structures [17]. However, the alternative placement of fucosylation does not alter the antibiofilm activity, as 3-FL also seems unable to penetrate into biofilm structures [42].

Compared to the 2 most investigated HMO structures, 2-FL and 3-FL, isolated HMO structures of larger size tend to exert more anti-pathogenic characteristics. LNFP I for example, a monofucosylated $\mathrm{LN}(\mathrm{n}) \mathrm{T}$ isomer which carries its Fuc in an $\alpha 1-2$ linkage at the terminal Gal and is the second most prevalent HMO (after 2-FL) [50], shows a high anti-pathogenic potential. LNFP I can significantly reduce pathogenic growth of GBS, while also exerting some antibiofilm action against GBS. In comparison with the other LNFP (LNFP II and LNFP III), LNFP I exerts the strongest antimicrobial potential. In addition, the anti-pathogenic properties of single HMOs were found to be strain-specific [42].

\subsubsection{Acidic Isolated HMO Structures}

The isolated structures described thus far are neutral, which make up a large fraction of all oligosaccharides present in human milk [51]. Sialylation of oligosaccharides produces a negatively charged entity under neutral conditions. However, this does not seem to affect their ability to inhibit pathogenic adhesion; inhibition of UPEC and Salmonella fyris by 3-SL, a sialylated oligosaccharide structure, is comparable to inhibition by 3-FL [17]. 6-SL has been shown to be effective in inhibiting pneumocyte invasion Pseudomonas aeruginosa strains [52], while larger sialylated human milk oligosaccharides, such as LS-tetrasaccharide a (LSTa) exhibit a strong antimicrobial activity against GBS [44].

\subsubsection{Fucosylated Oligosaccharides (FO)}

Fucose is present in human milk and the proportion of fucosylated HMOs in term breast milk was recently reported as 35-50\% [23]. FO are constructed covalently joining of the L-fucose molecules to other monosaccharides via glycosidic linkages. L-Fucose is abundantly present in brown algae, like Fucus, Laminaria, Sargassum, and Undaria spp, as a major constituent of fucoidan [53]. There is 
evidence supporting the inhibitory effects of fucoidan on Helicobacter infections by adhesion inhibition to mucosal surfaces [54]. Another study included fractions of HMOs, containing about 5-20 different high-mass glycans with different degrees of fucosylation, in a neoglycolipid array [55] and demonstrated that high-mass HMOs with oligovalent fucose can exhibit stronger binding capacities towards blood group-active mucin-type O-glycans compared with monovalent fucose HMOs. Furthermore, HMO fractions with the strongest binding capacities contained hepta-to decasaccharides expressing branches with terminal Lewis-b antigen or blood group H1 $[55,56]$. It has been recently proved that the presence of fucose alone does not correlate to antimicrobial activity, while the location and degree of fucosylation does play a key role in HMO antimicrobial activity [42].

Table 2. Overview of the anti-pathogenic functionalities of isolated HMOs.

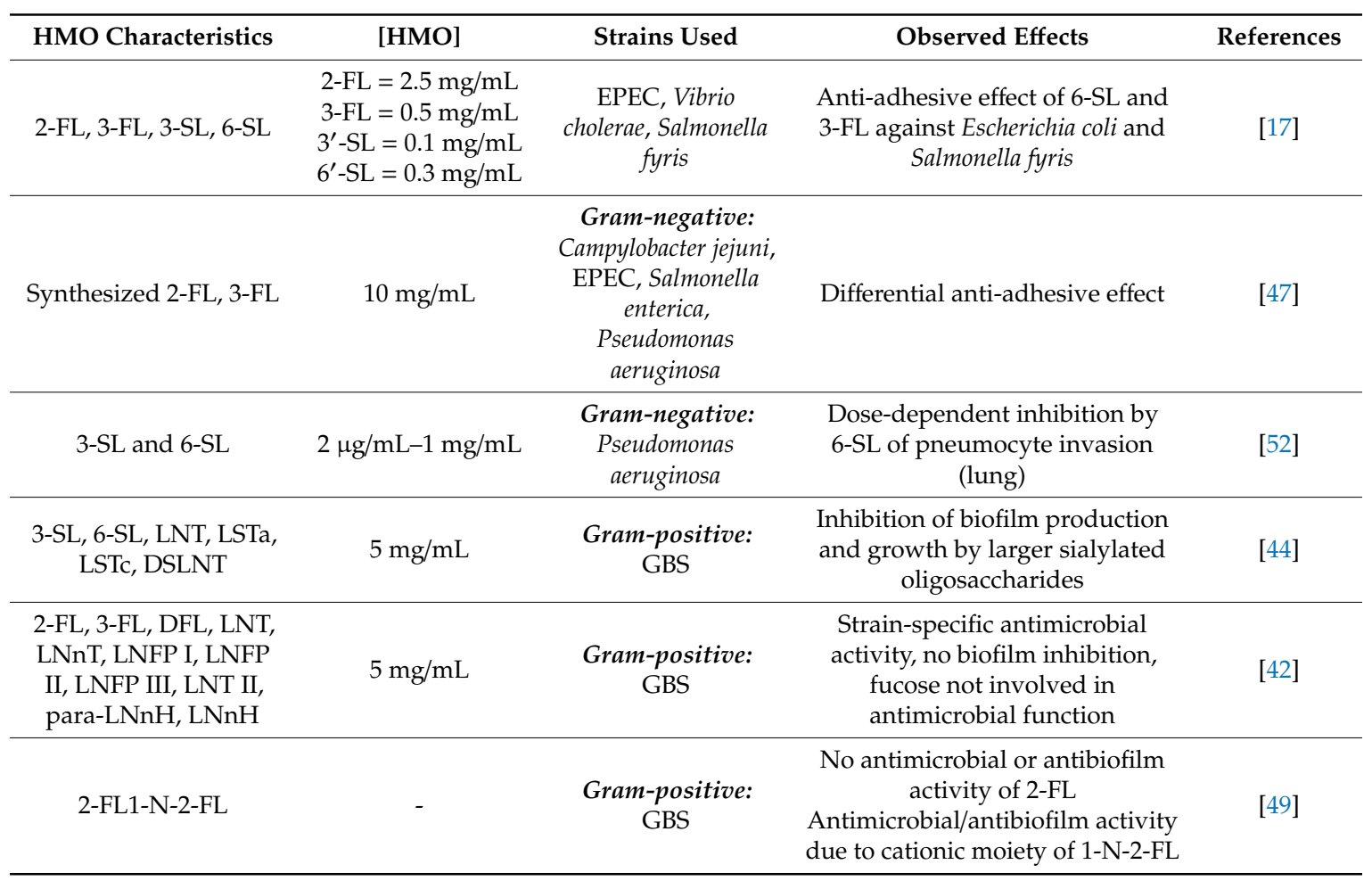

\section{Alginate Oligosaccharides}

\subsection{Structure}

Alginate is a biopolymer, present in the cell walls of brown algae, and is composed of a sequence of two types of monosaccharides, 1,4-linked $\beta-\mathrm{D}-$ mannuronic acid (M) and 1,4 $\alpha$-L-guluronic acid (G) (Figure 2) [57]. The $M / G$ monosaccharide ratio, expressed as guluronic content (GC), is an important indication for antimicrobial functioning, as the $G$ monomer has been shown to be preferred for cationic interaction as it is negatively charged [58]. From these polymers, AOS can be derived through enzymatic depolymerization or acid hydrolysis. So far, alginate biosynthesis has been detected in the Azotobacter vinelandii and the Pseudomonas species [59]. In Pseudomonas aeruginosa specifically, alginate biopolymers are an essential component of the biofilm EPS [60]. Alginates in these biofilms have slightly divergent structural characteristics, as they do not contain multiple G monosaccharides in sequence, termed G-blocks [61]. 


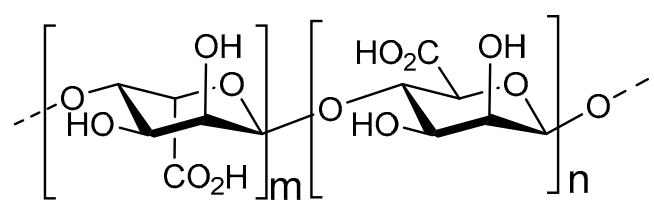

Figure 2. Structure of the main components of AOS; 1,4-linked $\beta$-D-mannuronic acid and 1,4-linked $\alpha$-L-guluronic acid.

\subsection{Anti-Pathogenic Functionalities}

AOS have many antimicrobial functionalities (Table 3), and three main mechanisms of antimicrobial potential can be identified, all of which affect biofilm growth and development. First, AOS inhibit pathogenic swarming motility and proliferation. Second, AOS elicit a $\mathrm{Ca}^{2+}$ chelating effect in the presence of bio-alginates. Finally, AOS affect expression of quorum-sensing (QS) genes. Importantly, most of the anti-pathogenic effects of AOS have been elucidated studying its effect on Pseudomonas aeruginosa, due to the alginate presence in the Pseudomonas aeruginosa biofilm composition.

\subsubsection{Biofilm Inhibition}

AOS have an extensive biofilm-inhibiting function. They inhibit pathogenic swarming and motility, important mediators in biofilm formation [62], in Gram-negative pathogenic strains Pseudomonas aeruginosa, Escherichia coli and Proteus mirabilis [63,64]. In Pseudomonas aeruginosa, inhibition of motility appears to be caused by AOS adhesion to the pathogenic exterior and flagella, along with a zeta-potential of the pathogenic cell surface by anionic AOS $[65,66]$. Inhibited motility and the resulting cellular aggregation has an inhibiting effect on the formation and growth of biofilms [67]. Even though alteration of surface-charge by AOS is limited to Gram-negative bacteria due to the polyanionic nature of the LPS layer of Gram-positive strains, AOS interaction with the LPS layer does induce biofilm-destructive bacterial aggregation of Streptococcus mutans [67]. Additionally, swarming of pathogenic cells and structured biofilm formation play an important role in the development of antibiotic resistance [68]. Indeed, AOS increase efficacy of several antibiotics against multidrug-resistant Pseudomonas aeruginosa $[63,66,69]$. Synergistic functionalities of AOS are not limited to antibiotics, as AOS adhesion to bacterial surface was also found to decrease colonization and biofilm formation in combination with an antibacterial and antifungal agent, triclosan [70].

\subsubsection{Metal ion Scavenging}

AOS are potent $\mathrm{Ca}^{2+}$ scavengers. The $\mathrm{Ca}^{2+}$ scavenging activities of AOS inhibit biofilm formation in a number of ways. $\mathrm{Ca}^{2+}$ crosslinks alginate biopolymers, one of the major components of the EPS, improving structure and stability of the biofilm [71,72] and contributing to Pseudomonas aeruginosa resistance to antibiotics and elements of the immune system $[73,74]$. By scavenging alginate-associated $\mathrm{Ca}^{2+}$ in the biofilm, AOS remove these crosslinks and compromises EPS integrity and increases susceptibility of the biofilm to antibiotic treatment $[63,66,69]$, which is in accordance with the observed higher affinity of $\mathrm{Ca}^{2+}$ for G-rich AOS [58]. Furthermore, considering $\mathrm{Ca}^{2+}$ availability induces alginate production Pseudomonas aeruginosa [75], AOS could also have a mediating function in the process of alginate-synthesis. The chelating properties are not universal to all bivalent cationic metals. $\mathrm{Fe}^{2+}$ for example, is another important factor in formation of the Pseudomonas aeruginosa biofilm and alginate production [76,77]. Contrary to $\mathrm{Ca}^{2+}, \mathrm{Fe}^{2+}$ is scavenged by neither AOS nor alginate [78].

\subsubsection{Quorum Sensing (QS) System Inhibition}

Finally, AOS inhibit expression of QS genes in Pseudomonas aeruginosa. QS signalling is a cell-to-cell communication through extracellular exchange of signalling molecules to coordinate pathogenic behaviour [79]. The system is responsible for bacterial adaptation to the environment and plays a role in biofilm formation, swarming behaviour and antibiotic resistance of Pseudomonas 
aeruginosa [80]. Additionally, through QS signalling, biofilm structure and integrity is influenced, for example through production of eDNA [81], an important component of the EPS of Pseudomonas aeruginosa, acting as a cellular connector $[82,83]$. AOS inhibit production of two of the main components of the QS signalling system, acyl homoserine lactones (AHL) and $\mathrm{C}_{4}-\mathrm{AHL}$ and 3-oxo- $\mathrm{C}_{12}-\mathrm{AHL}$ [84]. This effectively inhibits pathogenic swarming motility and biofilm formation. As AOS do not show specific interactions with DNA [69], modulation of QS signalling molecule expression is believed to be achieved through interaction between AOS and $\mathrm{C}_{4}-\mathrm{AHL}$ and $3-\mathrm{oxo}-\mathrm{C}_{12}-\mathrm{AHL}$. Consequently, the decline in intercellular signalling results in decreased synthesis of several virulence factors, such as elastase and pyocyanin [84]. Virulence factors exhibit important functionalities in biofilm persistence and antibiotic resistance [85]. Pyocyanin specifically inhibits production of eDNA [86]. Noticeably, AOS are able to make bacterial strains more susceptible to $\mathrm{H}_{2} \mathrm{O}_{2}$ by inhibiting QS-controlled virulence factors. QS affects the Pseudomonas aeruginosa resistance to $\mathrm{H}_{2} \mathrm{O}_{2}$ by production of antioxidants, such as superoxide dismutase and catalase, leading to the Pseudomonas aeruginosa resistance to the toxic free oxygen radicals $[87,88]$.

Table 3. Overview of the anti-pathogenic functionalities of AOS.

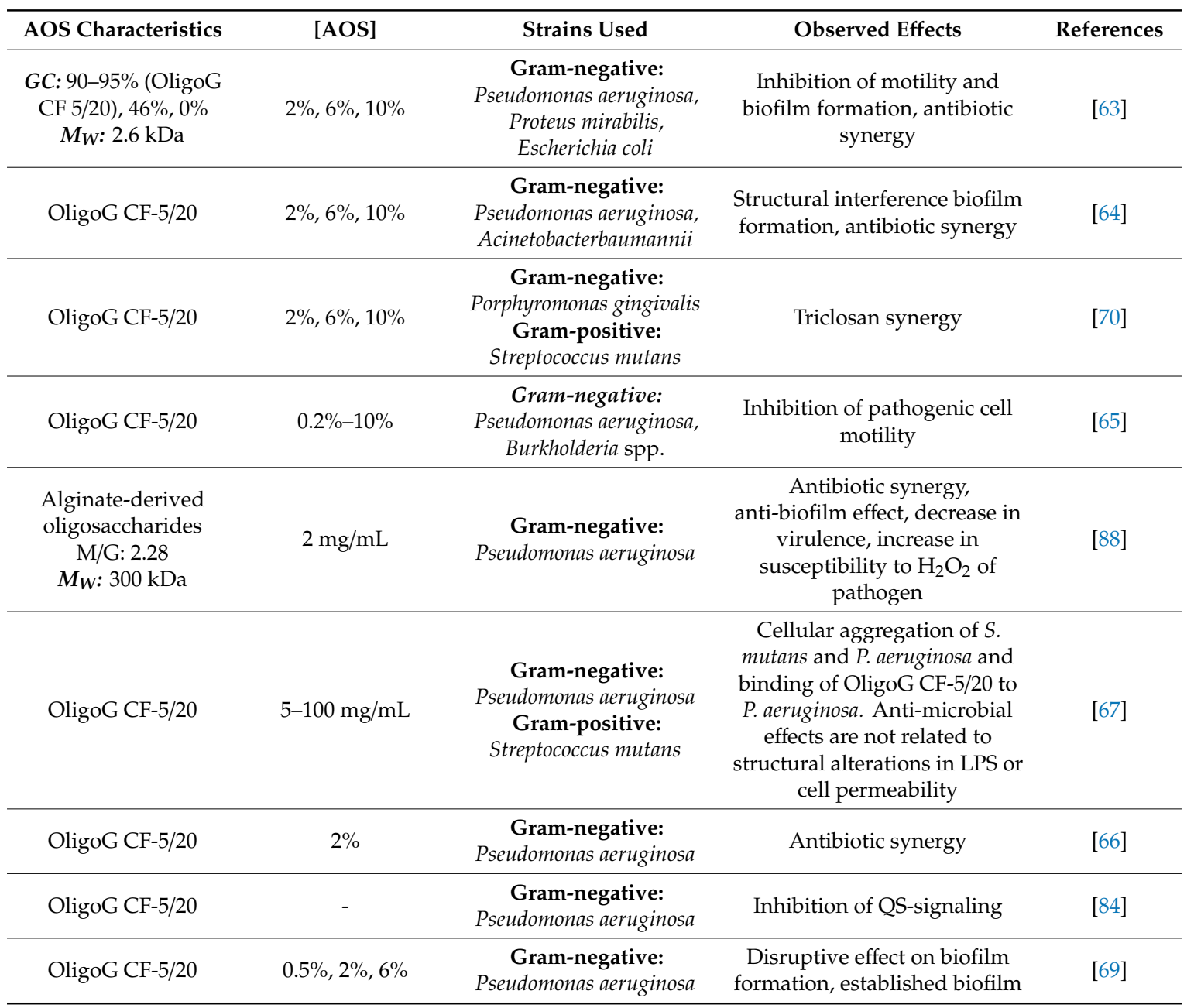

\section{Chito-Oligosaccharides/Chitosan Oligosaccharides}

\subsection{Structure}

One of the most extensively investigated oligosaccharides are COS. COS are enzymatically or chemically processed products of chitin or chitosan polymers. Chitin is abundantly present in crustacean or arthropodic shells, while chitosan is more rare and must be extracted from cell walls of 
specific fungi [89]. Crustacean and arthropodic chitin consists of $\beta-1,4$-linked $N$-acetyl-D-glucosamine (GlcNAc), whereas chitosan consists of GlcNAc and the deacetylated form $\beta-1,4$-linked D-glucosamine $(\mathrm{GlcN})$ (Figure 3). Chitin and chitosan copolymers are distinguished based on their DA: a DA of $>70 \%$ usually refers to chitin, whereas a DA of $<30 \%$ refers to chitosan [90]. The large chitin or chitosan polymers extracted from these biological sources, can be chemically or enzymatically hydrolysed into COS, with DP $<20$ and molecular weight of $<3900$ Da [91,92]. COS is highly soluble in a slightly acidic $\mathrm{pH}$ due to the charged state of the amine moiety (cationic nature) [93-95]. Chemically or enzymatically transformed COS is highly heterogenous with respect to DP and DA while the acetylation pattern (AP) can only be controlled to a certain extent [92,96]. Their enzymatic transformation allows for a limited control of the acetylation pattern [97]. GlcNAc is a ligand of F1C fimbriae in UPEC strains, involved in adhesion [98]. Nevertheless, antimicrobial effects of chitosan-based COS have been more extensively studied than chitin-based COS related to their increased solubility and cationic nature, making them more viable pharmacological prospects $[90,99,100]$.

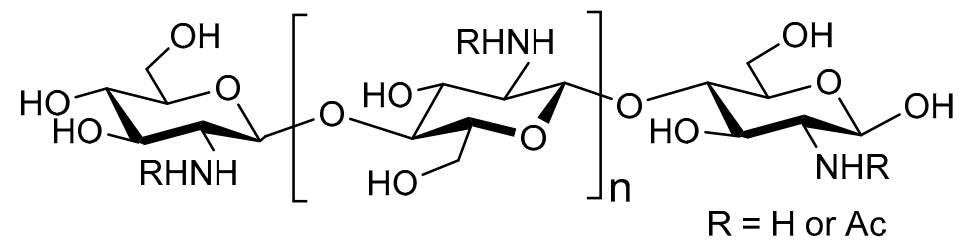

Figure 3. Structure of the main components of COS; with the monosaccharides N-acetylglucosamine (GlcN) and GlcNAc.

\subsection{Anti-Pathogenic Functionalities}

Ever since the antimicrobial activities of chitosan were first recognized [101], a wide range of studies have been conducted aiming to elucidate different antimicrobial pathways. A summary of the key antimicrobial activities of COS is presented in Table 4. First, COS have the potential to disrupt the bacterial cell membrane. Additionally, the surface-associating properties of COS can inhibit adhesion of pathogenic bacteria to host cells. COS also exhibit some antibiotic-potentiating properties and can inhibit RNA transcription in Gram-negative species. Importantly, different anti-pathogenic effects elicited by COS are often ambiguous amongst different sources. For example, the antimicrobial characteristics of COS are stronger against Gram-negative [95,102-104] or Gram-positive [93,94,105] bacterial strains, depending on the source.

\subsubsection{Cell Membrane Disruption}

Polymeric molecules bearing a cationic charge are known to adhere to Gram-negative bacterial cell surfaces by ionic interactions with anionic lipopolysaccharide patterns [106]. Polyethylenimine, for example, is of great interest in pharmaceutical research for its polycationic functionalities and capability [107,108]. For cationic glucosamine components, present in COS, a similar mechanism is proposed, creating an impermeable cationic oligosaccharide layer around the bacteria [102,109] Concomitantly, chitosan adherence to bacterial cell surface promotes leakage of electrolytes and metal ions from the bacterial lumen [110-112]. Metal ions and other nutrients essential for bacterial proliferation are unable to diffuse across the bacterial membranes [102,112]. Prolonged exposure to COS and the resulting osmotic imbalance results in inhibition of growth, cell swelling and, ultimately cell lysis [112,113]. The bactericidal activity of COS increases with an increased glucosamine share, and is greater than that of polymeric chitosan [114].

\subsubsection{Adhesion Inhibition}

Unlike other types of oligosaccharides, the anti-adhesive properties of COS have been relatively poorly studied. Yet, COS (DP $4>12$, DA 15-65\%) was found to be a potent, pathogen-specific inhibitor of EPEC adhesion, but not verotoxin-producing Escherichia coli (VTEC) [115,116]. Interestingly, 
although EPEC expressing F1C fimbriae were demonstrated to show affinity for GlcNAc, the DA hardly influences inhibition of pathogenic adherence [115]. An explanation for this is the abundance of strong ionic interactions mediated by the cationic amine moiety of glucosamine in addition to the GlcNAc recognition.

\subsubsection{Association with Bacterial DNA}

Chitosan has a strong interaction with fungal and plant DNA, mediated by electrostatic interactions, resulting in inhibited mRNA transcription [117-120]. Chitosan only penetrates into bacterial cells after disruption/lysing of the bacterial membrane $[112,113]$. COS, on the other hand, is linked to binding to bacterial DNA independent of bacterial lysis, inhibiting DNA transcription. This effect is most potent with $\operatorname{COS} \mathrm{M}_{\mathrm{w}} \leq 5000$ [121]. At this size, COS is small enough to penetrate the bacterial membrane [94,122]. COS interference with DNA transcription is linked to a decreased alginate production and, thus, biofilm formation in Pseudomonas aeruginosa [88]. mRNA transcription in Gram-negative species, however, is not affected in a similar manner, as their thick peptidoglycan layer prevents cellular penetration of COS [94,104].

\subsubsection{Synergy with Antibiotic Treatment}

Multi-drug resistance (MDR) is often achieved by bacteria by upregulation transmembrane multidrug efflux pumps [123]. COS sensitize multi-drug resistant Staphylococcus aureus and Pseudomonas aeruginosa to a number of common antibiotic formulations $[88,124,125]$, possibly through formation of the aforementioned cationic oligosaccharide layer around bacteria, or ionic interactions with multidrug efflux pumps.

Table 4. Overview of the anti-pathogenic functionalities of COS.

\begin{tabular}{|c|c|c|c|c|}
\hline COS Characteristics + Source & [COS] & Strains Used & Observed Effects & References \\
\hline $\begin{array}{l}\text { Chitosan oligosaccharides-from } \\
\text { chitosan with DA } 89 \% \\
\text { DP 3-6 (805) }\end{array}$ & $0.01-0.5 \%$ & $\begin{array}{l}\text { Gram-negative: } \\
\text { Escherichia coli }\end{array}$ & $\begin{array}{l}\text { Antibacterial activity } \\
\text { (anti-growth) and } 0.5 \% \\
\text { completely inhibited the } \\
\text { growth of } E \text {. coli }\end{array}$ & [126] \\
\hline $\begin{array}{l}\text { Chito-oligosaccharides DA } 8.5 \% \text {, } \\
\qquad \mathrm{M}_{\mathrm{W}} 2-30 \mathrm{kDa}\end{array}$ & $0.10 \%$ & $\begin{array}{l}\text { Gram-negative: } \\
\text { Aggregatibacter } \\
\text { actinomycetemcomitans } \\
\text { Gram-positive: } \\
\text { Streptococcus mutans }\end{array}$ & $\begin{array}{l}\text { Pathogenic membrane } \\
\text { disruption }\end{array}$ & [102] \\
\hline $\begin{array}{l}\text { Chito-oligosaccharides DA } 11 \% \\
\qquad \mathrm{M}_{\mathrm{W}}<10,<5,<1 \mathrm{kDa}\end{array}$ & $0.1-1 \%$ & $\begin{array}{l}\text { Gram-negative: Escherichia } \\
\text { coli, Salmonella typhimurium, } \\
\text { Pseudomonas aeruginosa } \\
\text { Gram-positive: Streptococcus } \\
\text { mutans, Micrococcus luteus, } \\
\text { Staphylococcus aureus, } \\
\text { Staphylococcus epidermidis, } \\
\text { Bacillus subtilis }\end{array}$ & $\begin{array}{l}\text { Higher anti-microbial } \\
\text { (anti-growth) effect } \\
\text { high- } \mathrm{M}_{\mathrm{w}} \text { COS }\end{array}$ & [105] \\
\hline Chitosan $\mathrm{M}_{\mathrm{W}} 5,8 \mathrm{kDa}$ & $0.01-0.5 \%$ & $\begin{array}{l}\text { Gram-negative: } \\
\text { Escherichia coli }\end{array}$ & $\begin{array}{l}\text { mRNA transcription } \\
\text { inhibition }\end{array}$ & [121] \\
\hline $\begin{array}{c}\text { Chitosans }\left(\mathrm{M}_{\mathrm{W}}=1671,1106,746,\right. \\
470,224, \text { and } 28 \mathrm{kDa}) \\
\text { Chitosan oligomers }\left(\mathrm{M}_{\mathrm{W}}=22,\right. \\
10,7,4,2, \text { and } 1 \mathrm{kDa})\end{array}$ & $1 \%$ & $\begin{array}{l}\text { Gram-negative: Escherichia } \\
\text { coli, Pseudomonas fluorescens, } \\
\text { Salmonella typhimurium, Vibrio } \\
\text { parahaemolyticus } \\
\text { Gram-positive: Listeria } \\
\text { monocytogenes, Bacillus } \\
\text { megaterium, Bacillus cereus, } \\
\text { Staphylococcus aureus }\end{array}$ & $\begin{array}{l}\text { Higher anti-microbial } \\
\text { effect (anti-growth) of } \\
\text { chitosan compared to COS } \\
\text { Chitosan showed stronger } \\
\text { bactericidal effects for } \\
\text { gram-positive bacteria } \\
\text { than gram-negative } \\
\text { bacteria }\end{array}$ & [93] \\
\hline
\end{tabular}


Table 4. Cont.

\begin{tabular}{|c|c|c|c|c|}
\hline COS Characteristics + Source & [COS] & Strains Used & Observed Effects & References \\
\hline $\begin{array}{c}\text { Chito-oligosaccharides DA } \\
\text { 35.2-37.8\% } \\
\text { DP 1-6 }\end{array}$ & $0.1-0.5 \%$ & $\begin{array}{c}\text { Gram-negative: } \\
\text { Escherichia coli } \\
\text { Gram-positive: Bacillus cereus }\end{array}$ & $\begin{array}{l}\text { Growth inhibition and cell } \\
\text { membrane disruption }\end{array}$ & [112] \\
\hline $\begin{array}{c}\text { Chito-oligosaccharides DA 3\%, } \\
\text { DP } \sim 4\end{array}$ & $0.25-2.5 \%$ & $\begin{array}{l}\text { Gram-negative: VTEC, EPEC, } \\
\text { Desulfovibrio desulfuricans }\end{array}$ & $\begin{array}{l}\text { Selective anti-adhesion } \\
\text { properties }\end{array}$ & [116] \\
\hline $\begin{array}{c}\text { Chito-oligosaccharides DA } \\
\text { 15-20\%, } \\
\mathrm{M}_{\mathrm{W}}<5,<3 \mathrm{kDa}\end{array}$ & $1-5 \%$ & $\begin{array}{c}\text { Gram-negative: } \\
\text { Escherichia coli } \\
\text { Gram-positive: } \\
\text { Staphylococcus aureus }\end{array}$ & $\begin{array}{l}\text { Antimicrobial effect } \\
\text { (anti-growth) on } \\
\text { Escherichia coli, but not } \\
\text { Staphylococcus aureus }\end{array}$ & [95] \\
\hline $\begin{array}{c}\text { Chitosan oligosaccharides- } \mathrm{M}_{\mathrm{W}}= \\
\text { 10,000 Da and } 1000 \mathrm{Da})- \text { from } \\
\text { chitosan with DA } 90-95 \%\end{array}$ & $0.5-10 \mathrm{mg} / \mathrm{mL}$ & $\begin{array}{l}\text { Gram-negative: } \\
\text { Vibrio vulnificus }\end{array}$ & $\begin{array}{l}\text { Higher antimicrobial effect } \\
\text { (anti-growth) of } \\
\text { water-soluble COS with } \\
\text { high molecular weight }\end{array}$ & [127] \\
\hline Chitosan DA >90\% & $0.0004-6.7 \%$ & $\begin{array}{c}\text { Gram-possitive: } \\
\text { Staphylococcus aureus (MDR) }\end{array}$ & $\begin{array}{c}\text { Synergy with several } A B \\
\text { treatments (anti-growth } \\
\text { effect) }\end{array}$ & [124] \\
\hline $\begin{array}{c}\text { Chitosans DA } 80-85 \% \\
\begin{array}{c}\mathrm{M}_{\mathrm{W}}=628,591 \text { and } 107 \mathrm{kDa} \\
\text { Chito-oligosaccharides DA } \\
80-85 \% \\
\mathrm{M}_{\mathrm{W}}=<5 \text { and }<3 \mathrm{kDa}\end{array}\end{array}$ & $0.5 \%$ & $\begin{array}{c}\text { Gram-negative: Escherichia } \\
\text { coli, Pseudomonas aeruginosa, } \\
\text { Klebsiella pneumoniae } \\
\text { Gram-positive: Staphylococcus } \\
\text { aureus, Staphylococcus } \\
\text { epidermidis }\end{array}$ & $\begin{array}{l}\text { Higher antimicrobial effect } \\
\text { (anti-growth) of the } 3 \\
\text { chitosans }\end{array}$ & [104] \\
\hline $\begin{array}{l}\text { Chito-oligosaccharides } \\
\text { DA 65\%, DP 3-5 }\end{array}$ & $2 \%$ & $\begin{array}{c}\text { Gram-negative: } \\
\text { Pseudomonas aeruginosa }\end{array}$ & $\begin{array}{l}\text { Anti-growth, anti-biofilm } \\
\text { functionalities and synergy } \\
\text { with azithromycin }\end{array}$ & [88] \\
\hline $\begin{array}{l}\text { Chito-oligosaccharides DA } \\
\text { 9-14\%, DP }<5-30\end{array}$ & $1-10 \%$ & $\begin{array}{c}\text { Gram-negative: } \\
\text { Escherichia coli } \\
\text { Gram-positive: Listeria } \\
\text { monocytogenes }\end{array}$ & $\begin{array}{l}\text { High antimicrobial effect } \\
\text { (anti-growth) with high DP }\end{array}$ & [103] \\
\hline $\begin{array}{l}\text { Chito-oligosaccharides-from } \\
\text { chitosan with DD } 80 \text { and } \\
90 \% \text {-from chitosan with } \mathrm{M}_{\mathrm{W}}= \\
5.1,14.3 \text { and } 41.1 \mathrm{kDa}\end{array}$ & $0.002-0.064 \%$ & $\begin{array}{l}\text { Gram-negative: Escherichia } \\
\text { coli, Salmonella typhimurium, } \\
\text { Salmonella enteritidis }\end{array}$ & $\begin{array}{l}\text { High antimicrobial effect } \\
\text { (anti-growth) with low DP, } \\
\text { potent ferrous chelating } \\
\text { activity at low DP }\end{array}$ & [128] \\
\hline
\end{tabular}

\section{Fructo-Oligosaccharides}

\subsection{Structure}

FOS are a common component of a healthy diet [129] and are widely investigated for their prebiotic functionalities. Sucrose (a glucose-fructose disaccharide) is transformed into fructose by a transfructosylating enzyme. The FOS structure is characterized by a single sucrose monomer followed by a variable number of fructose monomers, sometimes in a $2 \rightarrow 6$ but often with a $2 \rightarrow 1$ linkage (Figure 4). FOS structures larger than DP10 are termed inulin. 


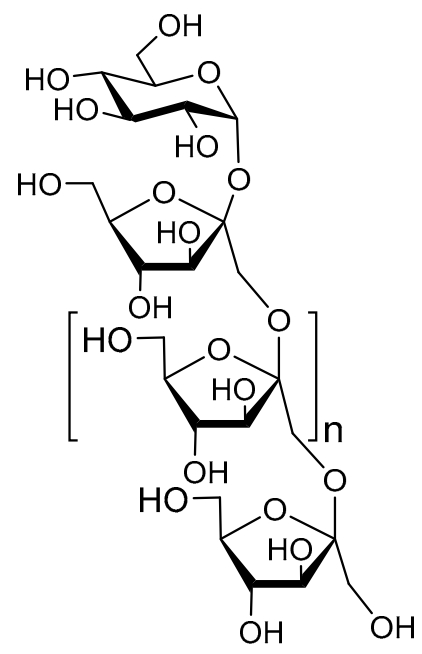

Figure 4. Structure of the main components of FOS; a glucose monomer, followed by an $n$ number of fructose monomers in sequence.

\subsection{Anti-Pathogenic Functionalities}

Although FOS are renowned for their indirect anti-pathogenic functionalities, namely their prebiotic capacity, direct anti-pathogenic functionalities of FOS are not widely investigated. FOS and inulin were associated with pathogenic anti-adhesion. Inulin inhibited the adhesion of Escherichia coli to human epithelial cells and FOS decreased the ability of Escherichia coli Nissle 1917 to adhere to human intestinal epithelial cells $[130,131]$. In addition, FOS decreased the growth, biofilm formation, and motility behaviour of Pseudomonas aeruginosa PAO1, while inulin showed the opposite effects. The FOS-induced decrease in exotoxin A, a P. aeruginosa virulence factor, could be a possible mechanism for the reduction in pathogenicity [132].

A number of causes may potentially underlie the scarcity of the anti-pathogenic functionalities of FOS. As we have seen, an oligosaccharide can serve as a substrate for a bacterial adhesin involved in pathogenic adhesion and offers a predictive value for the anti-adhesive functionalities. So far, FOS has not been associated with targeting any specific pathogenic adhesins and the existence has only been theorized [131]. Secondly, unlike several other oligosaccharides, FOS lack functional groups capable of bearing a charge. For this reason, FOS do not engage in ionic interaction the way (partially) charged oligosaccharides.

\section{Galacto-Oligosaccharides}

\subsection{Structure}

Although galactose is an important monosaccharide component of some HMOs, GOS are not a component of HMOs [25], but are known to mimic the biological effects of HMOs [133]. Commercially available GOS are most commonly composed of $\beta$-galactooligosaccharides instead of $\alpha$-galactooligosaccharides and usually have a DP ranging from 2 to 6 [134]. Typically, commercial GOS mixtures are structurally heterogenous due to enzyme activity, as they feature different types of linkages between monosaccharides. Most of these linkages are of $1 \rightarrow 4$ (Figure 5) or $1 \rightarrow 6$ in nature. Often, the enzymes used produce different types of linkages within one oligosaccharide, resulting in a range of different oligosaccharides in a mixture [135]. Unfortunately, many experiments performed with GOS have no clear characterization of the linkages of the used oligosaccharide mixture, and often an indication of the suspected GOS linkages are provided as a suggestion. Additionally, other types of oligosaccharides can be galactosylated, adding galactose characteristics. 


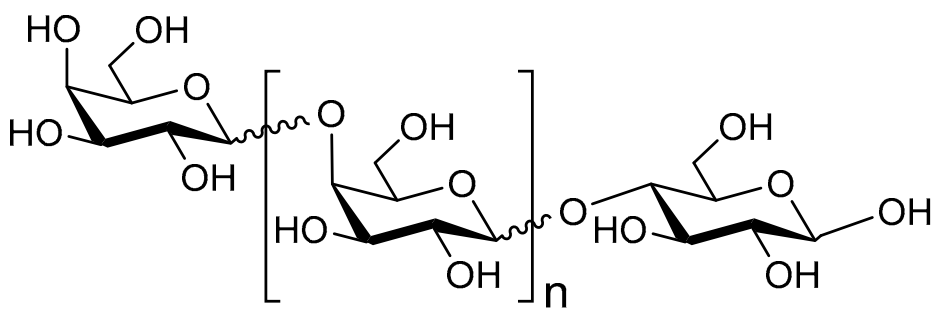

Figure 5. Structure of the main components of GOS; 1,4-linked and 1,6-linked $\beta$-galactose and a reducing-end glucose.

\subsection{Anti-Pathogenic Functionalities}

Two mechanisms of antimicrobial activity by GOS have been identified. GOS elicit anti-adhesive properties but can also inhibit host cell interaction with pathogenic toxins (Table 5).

\subsubsection{Adhesion Inhibition}

GOS interactions are attributed to their association to specific pathogenic adhesins. Some parasites, such as Entamoeba histolytica, use $\beta$-galactose patterns on intestinal epithelial cells for lectin mediated adhesion $[136,137]$. For this reason, GOS have been subject to investigation for the identification of a similar effect [138,139]. GOS were first reported to reduce cellular adhesion of EPEC [138], and later the anti-adhesive effect of GOS was shown for a number of other pathogenic strains, such as Salmonella typhimurium [139]. The anti-adhesive effect of GOS on Citrobacter rodentium is dependent on adhesin expression, as deduced from a diminished antiadhesive effect of GOS after expression alteration of fimbria-mediated genes [140]. This further suggests an adhesin-specific anti-adhesive effect of GOS. However, GOS did not show an anti-adhesive and anti-growth effect against Listeria monocytogenes [141]. Until now, a specific interaction between GOS and a pathogenic adhesin has not been identified. Interestingly, GOS significantly inhibit cellular adhesion of Cronobacter sakazakii [142], a strain suggested to exert a fimbria-independent mechanism of cellular adhesion [143]. Therefore, the anti-adhesive activity of GOS could (at least in part) be fimbria-independent.

\subsubsection{Anti-Toxin Binding}

Cholera toxin (Ctx) is produced and excreted by the Vibrio cholerae strain and binds to host cell surface GM-1 receptors, causing cellular salt and $\mathrm{H}_{2} \mathrm{O}$ excretion, resulting in diarrhea [144,145]. GM-1 receptors are lipid-conjugated oligosaccharides and contain a terminal galactose [146]. The GM-1 receptor, expressed on the membrane of intestinal epithelial cells, is responsible for Ctx entry into the host cell [147], although fucose binding is now also considered to be part of this [148]. GOS is hypothesized to bind to Ctx, inhibiting its GM-1 host cell entry mechanism [149] similar to dendritic GM1-oligoscaccharide compounds [150].

Table 5. Overview of the anti-pathogenic functionalities of GOS.

\begin{tabular}{|c|c|c|c|c|}
\hline GOS Characteristics & [GOS] & Strains Used & Observed Effects & References \\
\hline DP 3-7 & $0-32 \mathrm{mg} / \mathrm{mL}$ & $\begin{array}{l}\text { Gram-negative: } \\
\text { EPEC }\end{array}$ & Anti-adhesive effect & [138] \\
\hline DP 3-6 & $\begin{array}{c}1.56-100 \\
\mathrm{mg} / \mathrm{mL}\end{array}$ & $\begin{array}{l}\text { Gram-negative: } \\
\text { Vibrio cholerae }\end{array}$ & Anti-Ctx & [149] \\
\hline DP $1-4$ & $2.5 \mathrm{mg} / \mathrm{mL}$ & $\begin{array}{c}\text { Gram-negative: } \\
\text { Salmonella typhimurium }\end{array}$ & Anti-adhesive and anti-invasive effect & [139] \\
\hline DP 2-6 & $20 \mathrm{mg} / \mathrm{mL}$ & $\begin{array}{c}\text { Gram-positive: } \\
\text { Listeria monocytogenes }\end{array}$ & No anti-adhesive and anti-growth effect & [141] \\
\hline DP 3-6 & $16 \mathrm{mg} / \mathrm{mL}$ & $\begin{array}{l}\text { Gram-negative: } \\
\text { Cronobacter sakazakii }\end{array}$ & Anti-adhesive effect & [142] \\
\hline- & $10-50 \mathrm{mg} / \mathrm{mL}$ & $\begin{array}{l}\text { Gram-negative: } \\
\text { Citrobacter rodentium }\end{array}$ & Anti-adhesive effect & [140] \\
\hline
\end{tabular}




\section{Mannan-Oligosaccharides}

\subsection{Structure}

There are multiple ways of producing mannan-oligosaccharides (MOS). Previously, yeast products were harvested and directly applied for In vitro experimentation [151,152]. Nowadays, the most common ways of MOS production are chemical synthesis or autolysis of biopolymers extracted from yeast. Synthetically produced MOS can be structurally defined and nature of intergycosidic linkages can be determined [153]. Alternatively, isolation of autolysed yeast cell wall yields a heterogenous mixture of (branched) MOS, including $1 \rightarrow 2,1 \rightarrow 4$ and $1 \rightarrow 6$ D-mannose linkages [154]. The structure of MOS is shown in Figure 6. A drawback of MOS for pharmacological purposes is its branched nature and the unpredictability of the product structure after enzymatic production.

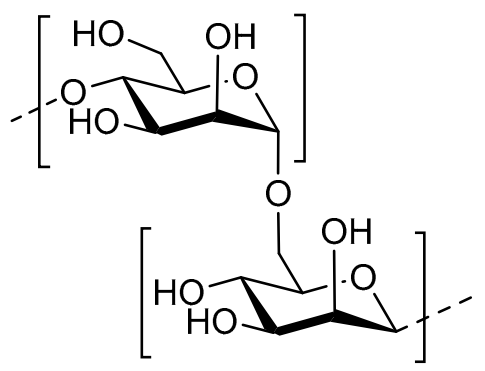

Figure 6. Structure of the main components of MOS; $1 \rightarrow 4$ linked D-mannose (top) and $1 \rightarrow 6$ linked D-mannose (bottom).

\subsection{Anti-Pathogenic Functionalities}

The mannose monosaccharides and MOS are well-known for their anti-adhesion capacity against pathogen adhesion, as summarized in Table 6.

\section{Adhesion Inhibition}

The mannose monosaccharide is an established and widely studied ligand for the FimH domain of type I fimbriae. The FimH domain of the type I fimbria is responsible for recognition of mannose patterns on host cell exterior and subsequent mannose-dependent pathogenic adhesion $[155,156]$. Type I fimbriae are commonly found in Salmonella spp. and Escherichia coli and play an important role in adhesion by binding to mannose patterns in host cell epithelial receptors [151,152,157]. It was previously shown that glycosides of mannose exhibit amplified anti-adhesive properties towards Escherichia coli compared to mannose monosaccharides, indicating the importance of a hydrophobic region in the vicinity of the mannose binding area for type I fimbria adhesion [158,159]. Mannose can bind to different FimH variants from different Escherichia coli pathotypes, concluding that mannose affinity for the FimH domain is independent of pathotype [160]. The mannose binding pocket of the FimH was later determined to be identical within different pathogenic species, including Escherichia coli and Klebsiella pneumonia [161]. As mannose glycosides have a significantly higher affinity for the Klebsiella pneumonia, it is likely that FimH structure varies between species and are also presented differently [161]. This difference is also reflected in superior Escherichia coli specificity for mono-or trimannose moieties [162,163]. Furthermore, significant reduction in the adherence of Campylobacter jejuni and coli to human epithelial cells was observed in the presence of MOS [163]. An overview of anti-adhesion activities is shown in Table 6. MOS binds to the FimH domain in competition with mannose patterns on host epithelial cells. This inhibits pathogenic adhesion by exerting a receptor-mimicking function $[164,165]$. Contrary to the mannose monosaccharide described earlier, addition of hydrophobic triethylene glycol to MOS (DP $\geq 3$ ) does not increase the affinity for FimH compared to unconjugated MOS [160]. Inhibition of pathogenic adhesion by MOS is non-superior to inhibition by yeast cell wall, containing mannose biopolymers [166]. 
Table 6. Overview of the anti-pathogenic functionalities of MOS.

\begin{tabular}{ccccc}
\hline MOS Characteristics & [MOS] & Strains Used & Observed Effects & References \\
\hline DP 2-6 & $0.1-0.5 \mathrm{mM}$ & $\begin{array}{c}\text { Gram-negative: } \\
\text { Escherichia coli }\end{array}$ & Anti-adhesive effect & [167] \\
\hline DP 9 & $25 \mu \mathrm{M}$ & $\begin{array}{c}\text { Gram-negative: } \\
\text { Enterobacter cloacae }\end{array}$ & Anti-adhesive effect & {$[168]$} \\
\hline DP 3 MOS & $0.13 \mathrm{M}-087 \mathrm{M}$ & $\begin{array}{c}\text { Gram-negative: } \\
\text { Escherichia coli }\end{array}$ & $\begin{array}{c}\text { Affinity for FimH } \\
\text { mannose }>\text { MOS }\end{array}$ & [160] \\
\hline $\begin{array}{c}\text { Partially purified yeast MOS } \\
\text { and soluble supernatant } \\
\text { fraction of MOS }\end{array}$ & $10-50 \mathrm{mg} / \mathrm{mL}$ & $\begin{array}{c}\text { Gram-negative: } \\
\text { Campylobacter jejuni, } \\
\text { Campylobacter coli }\end{array}$ & Anti-adhesive effects & [163] \\
\hline Yeast MOS & $6 \mathrm{mg} / \mathrm{mL}$ & $\begin{array}{c}\text { Gram-negative: } \\
\text { Escherichia coli, } \\
\text { Salmonella pullorum }\end{array}$ & $\begin{array}{c}\text { Anti-adhesive effect } \\
\text { (less effective than } \\
\text { yeast cell walls) }\end{array}$ & [166] \\
\hline
\end{tabular}

\section{Pectic Oligosaccharides}

\subsection{Structure}

Pectin is a plant biopolymer, acting as a stabilizer for the cellulose network [169]. Pectin is a complex biopolymer made up of combined monosaccharides, most importantly $(1 \rightarrow 4)$ linked D-galacturonic acid (GalA). GalA is the main component of the pectin backbone, with a L-rhamnose content of 2-4\% (Figure 7) [170]. GalA monosaccharides of pectin biopolymers are 6-methyl esterified to a certain extent, depending on the presence of pectin esterase in the source [171]. Much like acetylation of chitosan, the extent to which pectin is methylated dictates its function; low methylation ensures higher hydrophilicity and more interaction with cationic metal agents [172]. Depolymerization of pectin yields POS, which can due to the high diversity of the source polysaccharide, assume a high variety of forms. POS investigated for antimicrobial purposes are often depolymerized by enzymatic hydrolysis and are often derived from orange/bergamot peel $[173,174]$. Pectin found in bergamot peel is especially useful due to presence of 'hairy' and 'smooth' regions of GalA backbone. Hairy regions of pectin are equipped with arabinose, galactose, glucose, mannose and xylose elements [175]. This way, a large number of structurally different oligosaccharides can be synthesized from a single source.

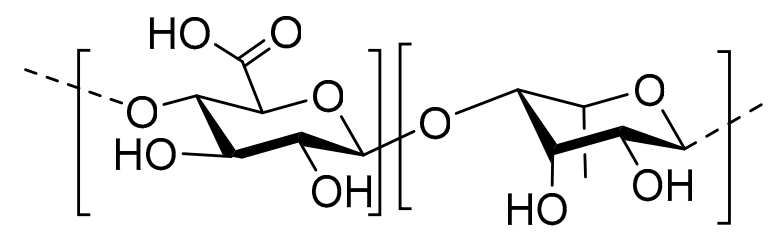

Figure 7. Structure of the main components of POS; a non-methylated D-galacturonic acid monomer (left) linked in a $\beta 1 \rightarrow 4$ fashion with a rhamnose monomer (right).

\subsection{Anti-Pathogenic Functionalities}

POS have a wide range of antimicrobial activity as summarized in Table 7. POS have the capability to inhibit growth of several pathogens, inhibit adhesion of pathogenic bacteria and can also interact with pathogen-produced Shiga-like toxins (Stx).

\subsubsection{Growth Inhibition}

Although multiple types of POS have shown to inhibit pathogenic growth, no mechanism has been determined thus far. Citric POS inhibit growth of a number of pathogenic strains, with superior efficacy of growth inhibition of low $\mathrm{M}_{\mathrm{w}}$ POS for all inhibited strains [176]. The mechanism through which inhibition is achieved seems to be strain-dependent, as Gram-negative Campylobacter jejuni 
growth remains unaffected [177]. POS extracted from haw fruit show inhibition of pathogen growth at relatively low concentrations compared to citrus-extracted POS, although the mechanism through which inhibition is achieved remains unclear [178]. The induced strain-dependent growth inhibition could be related to increased radical scavenging abilities of charged POS. However, unlike COS and AOS, unspecific ionic interaction of charged carboxylic acid groups with the pathogenic exterior is unlikely to be the main source of pathogenic growth inhibition by POS, as it is strain-dependent.

\subsection{2. $\mathrm{CO}_{2}$ Radical Production}

POS have shown to efficiently scavenge free radicals $[179,180]$. Free radicals, such as HO•, have a number of pathological effects, such as DNA damage and carcinogenesis [181,182]. Radical-scavenging substances have been widely studied for their attractive pharmacological properties [183]. Interestingly, $\mathrm{HO} \bullet$ radical scavenging appears to trigger $\mathrm{CO}_{2} \bullet-$ radical production by several different types of POS, which is hypothesized to inhibit Staphylococcus aureus and, less significantly, Escherichia coli growth [184]. However, due to the versatility of POS characteristics, the anti-pathogenic effect of $\mathrm{CO}_{2} \bullet^{-}$, if any, has not been successfully gauged.

\subsubsection{Adhesion Inhibition}

POS inhibit adhesion of several kinds of pathogenic strains, most notably, Escherichia coli. The anti-adhesive mechanism referred to is inhibition of P-fimbria-mediated adhesion [185-187]. The extent of inhibition exhibited by POS seems to be beneficially influenced by high GalA content and low degree of 6-methyl esterification [188]. However, the P-fimbriae-specific inhibition of adhesion is not supported by the presence of a GalA binding pocket on these P-fimbriae [186,188]. For this reason, the exact mechanism of fimbria-specific inhibition of adhesion is still unclear. Additionally, high uronic acid content in POS and, consequently, higher ionic interactions between oligosaccharides and pathogens have been proposed to contribute to the anti-adhesion functionalities against Gram-positive Staphylococcus aureus bacteria. Interestingly, uronic acid-rich oligosaccharides did not prove effective for inhibition of adhesion of Escherichia coli [189].

Table 7. Overview of the anti-pathogenic functionalities of POS.

\begin{tabular}{|c|c|c|c|c|}
\hline $\begin{array}{c}\text { POS Characteristics }+ \\
\text { Source }\end{array}$ & [POS $]$ & Strains Used & Observed Effects & References \\
\hline $\begin{array}{c}\mathrm{M}_{\mathrm{W}} 1-4 \mathrm{kDa} \text { Citrus (high } \\
\text { methylation) } \\
\text { Apple (low methylation) }\end{array}$ & $10 \mathrm{mg} / \mathrm{mL}$ & $\begin{array}{c}\text { Gram-negative: Escherichia coli } \\
\text { O157:H7 Shiga toxin }\end{array}$ & $\begin{array}{l}\text { Inhibition of host cell } \\
\text { infiltration of Stx }\end{array}$ & [185] \\
\hline $\begin{array}{c}\mathrm{M}_{\mathrm{W}} 1-12 \mathrm{kDa} \text { Panax } \\
\text { ginseng }\end{array}$ & $0.01-0.5 \mathrm{mg} / \mathrm{mL}$ & $\begin{array}{c}\text { Gram-negative: Aggregatibacter } \\
\text { actinomycetemcomitans } \\
\text { Gram-positive: Staphylococcus } \\
\text { aureus }\end{array}$ & Anti-adhesive effect & {$[189]$} \\
\hline DP 2-3 Orange peel & $2.5 \mathrm{mg} / \mathrm{mL}$ & $\begin{array}{l}\text { Gram-negative: EPEC, VTEC, } \\
\text { Desulfovibrio desulfuricans }\end{array}$ & Anti-adhesive effect & {$[186]$} \\
\hline $\begin{array}{c}\text { GalA:Rhamnose 1:1 } \\
\text { Albedo of orange peel }\end{array}$ & $0.05-2.5 \mathrm{mg} / \mathrm{mL}$ & $\begin{array}{c}\text { Gram-negative: Campylobacter } \\
\text { jejuni }\end{array}$ & $\begin{array}{l}\text { Inhibited Caco- } 2 \text { cell } \\
\text { invasion }\end{array}$ & {$[177]$} \\
\hline $\begin{array}{c}0.2-6 \mathrm{kDa} 93.6 \% \text { Uronic } \\
\text { acid Haw }\end{array}$ & $1-10 \mathrm{mg} / \mathrm{mL}$ & Gram-negative: Escherichia coli & $\begin{array}{l}\text { Antimicrobial activity } \\
\text { dependent on } \\
\text { concentration and low } \mathrm{pH}\end{array}$ & [178] \\
\hline DP 6-19 Orange peel & $1-100 \mathrm{mg} / \mathrm{mL}$ & $\begin{array}{c}\text { Gram-negative: Escherichia coli } \\
\text { Gram-positive: Staphylococcus } \\
\text { aureus, Bacillus subtilis }\end{array}$ & $\begin{array}{l}\text { Antimicrobial activity-low } \\
\text { Mw more effective }\end{array}$ & {$[176]$} \\
\hline $\begin{array}{c}\text { Apple, citrus, } \\
\text { polygalacturonic acid }\end{array}$ & $0.1 \mathrm{mg} / \mathrm{mL}$ & $\begin{array}{c}\text { Gram-negative: Escherichia coli } \\
\text { Gram-positive: Staphylococcus } \\
\text { aureus }\end{array}$ & $\begin{array}{l}\text { Growth inhibition, } \\
\text { potentially through } \mathrm{CO}_{2} \\
\text { radical production }\end{array}$ & [184] \\
\hline $\mathrm{M}_{\mathrm{W}}$ 9-73 kDa Orange peel & $0.005-5 \mathrm{mg} / \mathrm{mL}$ & $\begin{array}{c}\text { Gram-negative: Shigatoxigenic } \\
\text { Escherichia coli }\end{array}$ & $\begin{array}{l}\text { Anti-adhesive effect, direct } \\
\text { interaction with Stx }\end{array}$ & [188] \\
\hline
\end{tabular}




\subsubsection{Inhibition of Toxin-Binding}

Shigatoxigenic Escherichia coli produce Stx type 1 as well as type 2. The pentamer subunit of Stx, termed StxB interacts with a number host cell surface constituents, the main one globotriaosylceramide (Gb3), for epithelial cell internalization $[190,191]$. The Gb3 receptor is a lipid-conjugated oligosaccharide structure consisting of a Gal $\alpha 1,4 \mathrm{Gal} \beta 1,4 \mathrm{Glc}$ trisaccharide [192]. Even though Stx type 1 and type 2 do not necessarily always use the same pathways to enter cells [193], POS inhibit the host cell uptake of both types of Shiga toxin in two ways. First, GalA-rich POS is associated with competitive binding of Gb3 with Shiga toxin. GalA inhibitory capacity of Gb3 is similar to that of its primary substrate [188]. Additionally, POS directly binds to Stx, due to structural similarities between POS and the galabiose receptor. This interaction inhibits Stx association to the $\mathrm{Gb} 3$ receptor, to a comparable extent to inhibition by the minimum receptor analogue galabiose (Gal $\alpha 1,4 \mathrm{Gal}$ ) [194], reducing host cell uptake of Stx [185]. Similarly, the Stx-binding capabilities of POS have been proposed to assist in inhibiting Campylobacter jejuni infiltration into host epithelial cells [177]. This interaction provides a long-term disabling effect and possibly even structural alteration of the bound toxin [188] which could prove useful in clinical application considering Stx, in conjunction to their ability to infiltrate host epithelial cells, also infiltrates underlying tissues [195].

\section{Conclusions and Future Perspectives}

In vitro investigation of NDOs has unveiled a wide range of anti-pathogenic functionalities, including anti-adhesion properties against pathogens, inhibition of biofilm formation, inhibition of specific pathogen growth and toxin-binding properties. An overview of these anti-pathogenic functionalities with corresponding NDOs is illustrated in Figure 8.

Most of the anti-pathogenic functionalities elicited by a specific oligosaccharide can be predicted by investigation of a number of characteristics, for example, the presence of a pathogenic adhesin or toxin that may bind to the carbohydrate sequence and/or potential charge of the oligosaccharide. However, structural features of oligosaccharides responsible for their adhesin-specific anti-adhesion properties are not necessarily related to mechanisms of other anti-pathogenic activities. Ionic interaction between charged oligosaccharides and pathogenic exterior can cause decreased motility and transport of nutrition, while some NDOs may electrostatically interact with intracellular DNA, inhibiting DNA-transcription.

Although several mechanisms of anti-pathogenic functioning have been identified, not all studies propose a clear explanation for the observed anti-microbial properties, and there are also contradictory reports concerning the antimicrobial potential of several NDOs against different types of microbial strains. A better characterization of the oligosaccharides in terms of DP, DA and monosaccharide sequence and testing a wider range of pathogens could assist in further uncovering details of anti-pathogenic functionalities. Glycan (or carbohydrate) arrays (e.g., using glycan probes) could also contribute to fast and high-throughput screening of protein-carbohydrate interactions with small amounts of carbohydrate ligands [196,197].

For clinical application, monotherapy with single adhesin-specific NDOs will have limited chance of successfully inhibiting pathogen adhesion, due to the variability of pathogenic adhesin expression. Rather, a mixture of NDOs with affinity for different adhesins could have a higher clinical applicability and in general, NDOs are not pure products, but are mixtures containing oligosaccharides of different DP.

For direct inhibition of pathogens, charged NDOs are more interesting to the clinical environment compared to uncharged NDOs due to lower pathogen-specificity, not relying on expression of a specific pathogenic adhesin. Non-food application, including local application via lung or skin, can be proposed for future investigation. Before we can make any statements about future applications requiring systemic delivery of NDOs, assessment of systemic stability, toxicity and immunogenicity of NDOs is needed. 
In conclusion, versatility of antimicrobial effects, their unique ability to penetrate and inhibit biofilm structures and their limited side effects plea for oligosaccharides as a useful tool in the battle against emerging infections and antibiotic resistance. In addition, the effects of NDOs on promoting beneficial bacteria in the gut should not be neglected, since a well-balanced microbiota contributes to protection against infections by inhibiting pathogenic bacteria or by orchestrating appropriate immune responses.

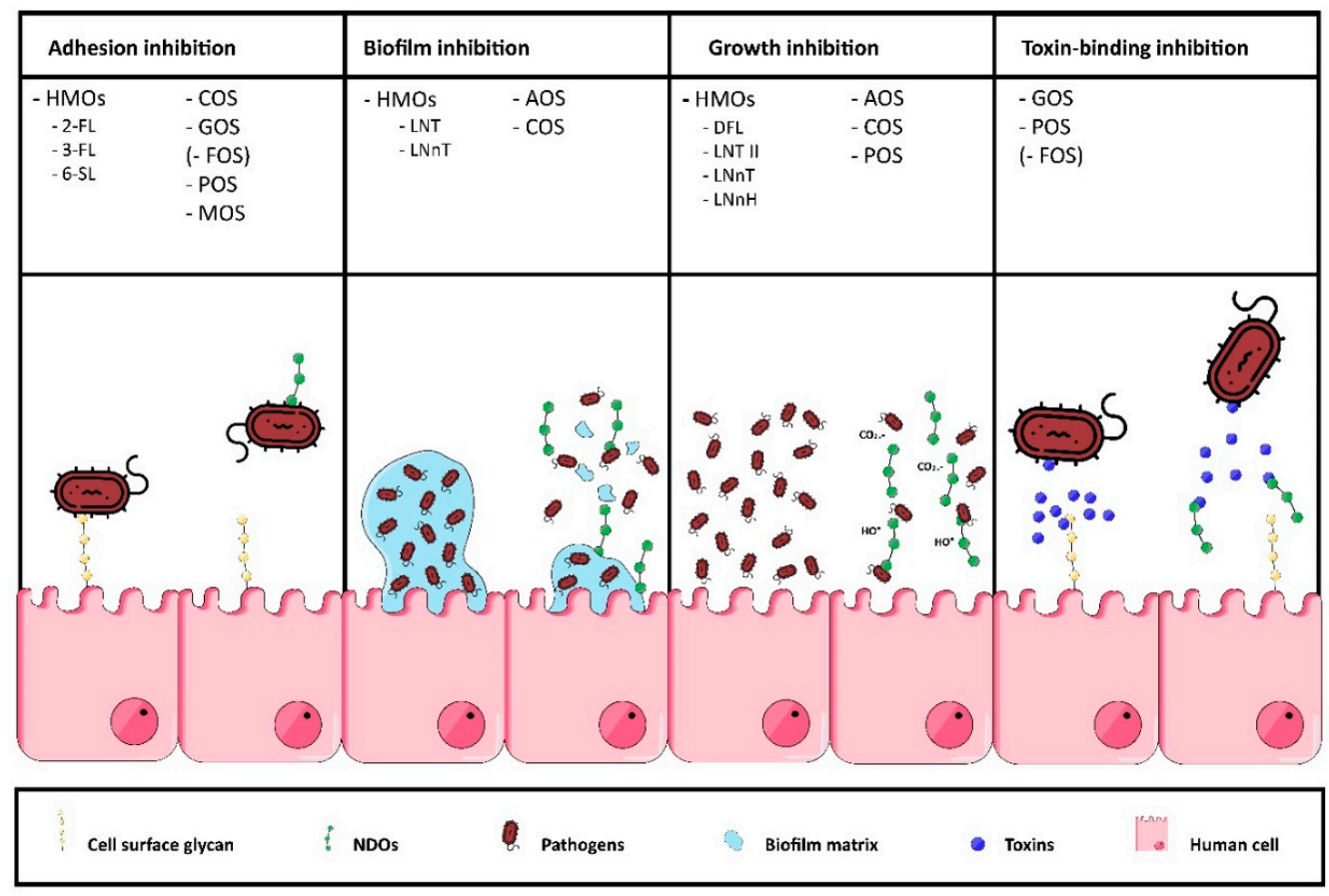

Figure 8. Schematic overview of the anti-pathogenic functionalities of NDOs in vitro. The first column shows that different NDOs (different HMOs, COS, GOS, FOS, POS and MOS) can serve as decoy receptors that competitively bind pathogens, which prevents pathogen adhesion to cell surface glycans. The second column indicates that several HMOs, AOS and COS can inhibit biofilm formation by penetrating and interacting with elements of the pathogenic biofilm. Multiple NDOs, such as, different HMOs, AOS, COS and POS, have shown to inhibit pathogenic growth, for example, by disrupting the bacterial cell membrane and/or by scavenging free radicals, such as $\mathrm{HO} \bullet$, which have a number of pathological effects (third column). The fourth column indicates that several NDOs (GOS, POS, FOS) can inhibit host cell interaction with pathogenic toxins.

Author Contributions: Conceptualization, M.A. and S.B.; Writing original draft C.P., M.A., and S.B.; Writing-review and Editing, S.B., G.F., R.J.P., S.V. and P.A.J.H.; Table and Figure creation, M.A., C.P. and S.B. All authors have read and agreed to the published version of the manuscript.

Funding: This research received no external funding.

Conflicts of Interest: The authors declare no conflict of interest.

\section{Abbreviations}

$\begin{array}{ll}\text { 2-FL } & \text { 2-Fucosyllactose } \\ \text { 3-FL } & \text { 3-Fucosyllactose } \\ \text { 3-SL } & \text { 3-Sialyllactose } \\ \text { 6-SL } & \text { 6-Sialyllactose }\end{array}$

$\alpha 1,2$-fucose FUT2

$\alpha 1,4$-fucose FUT3

AHL Acyl homoserine lactones

AOS Alginate oligosaccharide 


$\begin{array}{ll}\text { AP } & \text { Acetylation pattern } \\ \text { COS } & \text { Chito-oligosaccharides/chitosan oligosaccharides } \\ \text { Ctx } & \text { Vibrio cholerae toxin } \\ \text { DA } & \text { Degree of acetylation } \\ \text { DD } & \text { Degree of deacetylation } \\ \text { DP } & \text { Degree of polymerization } \\ \text { EPEC } & \text { Enteropathogenic Escherichia coli } \\ \text { EPS } & \text { Extracellular polymeric substances } \\ \text { FO } & \text { Fucosylated oligosaccharides } \\ \text { FOS } & \text { Fructo-oligosaccharides } \\ \text { Gal } & \text { Galactose } \\ \text { GBS } & \text { Group B Streptococcus } \\ \text { Gb3 } & \text { Globotriaosylceramide } \\ \text { GC } & \text { Guluronic content } \\ \text { Glc } & \text { Glucose } \\ \text { GlcN } & \text { ß-1,4-linked D-glucosamine } \\ \text { GlcNAc } & \text { N-acetylglucosamine } \\ \text { GOS } & \text { Galacto-oligosaccharides } \\ \text { HMOs } & \text { Human milk oligosaccharides } \\ \text { HMWF } & \text { High-molecular weight fraction } \\ \text { LMWF } & \text { Low-molecular weight fraction } \\ \text { LNFP I } & \text { Lacto-N-fucopentaose I } \\ \text { LNT } & \text { Lacto-N-tetraose } \\ \text { LSTa } & \text { LS-tetrasaccharide a } \\ \text { MOS } & \text { Mannan-oligosaccharides } \\ \text { NDOs } & \text { Non-digestible oligosaccharides } \\ \text { POS } & \text { Pectic oligosaccharides } \\ \text { QS } & \text { Quorum-Sensing } \\ \text { Stx } & \text { Shiga toxin } \\ \text { UPEC } & \text { UroPathogenic Escherichia coli } \\ \text { VTEC } & \text { Verocytotoxin-producing Escherichia coli } \\ & \end{array}$

\section{References}

1. Mussatto, S.I.; Mancilha, I.M. Non-digestible oligosaccharides: A review. Carbohydr. Polym. 2007, 68, 587-597. [CrossRef]

2. Akbari, P.; Fink-Gremmels, J.; Willems, R.H.A.M.; Difilippo, E.; Schols, H.A.; Schoterman, M.H.C.; Garssen, J.; Braber, S. Characterizing microbiota-independent effects of oligosaccharides on intestinal epithelial cells: Insight into the role of structure and size: Structure-activity relationships of non-digestible oligosaccharides. Eur. J. Nutr. 2017, 56, 1919-1930. [CrossRef] [PubMed]

3. Schouten, B.; van Esch, B.C.A.M.; Kormelink, T.G.; Moro, G.E.; Arslanoglu, S.; Boehm, G.; Knippels, L.M.J.; Redegeld, F.A.; Willemsen, L.E.M.; Garssen, J. Non-digestible oligosaccharides reduce immunoglobulin free light-chain concentrations in infants at risk for allergy. Pediatr. Allergy Immunol. 2011, 22, 537-542. [CrossRef] [PubMed]

4. Algieri, F.; Rodríguez-Nogales, A.; Garrido-Mesa, N.; Vezza, T.; Garrido-Mesa, J.; Utrilla, M.P.; Montilla, A.; Cardelle-Cobas, A.; Olano, A.; Corzo, N.; et al. Intestinal anti-inflammatory effects of oligosaccharides derived from lactulose in the trinitrobenzenesulfonic acid model of rat colitis. J. Agric. Food Chem. 2014, 62, 4285-4297. [CrossRef] [PubMed]

5. Okeke, I.N.; Aboderin, O.A.; Byarugaba, D.K.; Ojo, K.K.; Opintan, J.A. Growing problem of multidrugresistant enteric pathogens in Africa. Emerg. Infect. Dis. 2007, 13, 1640-1646. [CrossRef]

6. Humphries, R.M.; Schuetz, A.N. Antimicrobial susceptibility testing of bacteria that cause gastroenteritis. Clin. Lab. Med. 2015, 35, 313-331. [CrossRef]

7. Willyard, C. The drug-resistant bacteria that pose the greatest health threats. Nature 2017, 543, 15. [CrossRef]

8. Flemming, H.-C.; Wingender, J. The biofilm matrix. Nat. Rev. Microbiol. 2010, 8, 623-633. [CrossRef] 
9. Qiang, X.; YongLie, C.; QianBing, W. Health benefit application of functional oligosaccharides. Carbohydr. Polym. 2009, 77, 435-441. [CrossRef]

10. Cai, Y.; Folkerts, G.; Maurer, M. Microbiota-Dependent and-Independent effects of dietary fibre on human health. Br. J. Pharmacol. 2020, 177, 1363-1381. [CrossRef]

11. Haak, B.W.; Prescott, H.C.; Wiersinga, W.J. Therapeutic Potential of the Gut Microbiota in the Prevention and Treatment of Sepsis. Front. Imunnol. 2018, 9, 1-8. [CrossRef] [PubMed]

12. 1Vitetta, L.; Vitetta, G.; Hall, S. Immunological Tolerance and Function: Associations Between Intestinal Bacteria. Probiotics 2018, 9, 1-15.

13. Bernardi, A.; Jiménez-barbero, J.; Casnati, A.; Castro, C. De Multivalent glycoconjugates as anti-pathogenic agents. Chem. Soc. Rev. 2015, 42, 4709-4727. [CrossRef] [PubMed]

14. Shoaf-Sweeney, K.D.; Hutkins, R.W. Chapter 2 Adherence, Anti-Adherence, and Oligosaccharides. Preventing Pathogens from Sticking to the Host. Adv. Food Nutr. Res. 2008, 55, 101-161.

15. Rosenberg, M.; Bayer, E.A.; Delarea, J.; Rosenberg, E. Role of Thin Fimbriae in Adherence and Growth of Acinetobacter calcoaceticus RAG-1 on Hexadecane. Appl. Environ. Microbiol. 1982, 44, 929-937. [CrossRef]

16. Duguid, J.P.; Old, D.C. Adhesive Properties of Enterobacteriaceae BT. In Bacterial Adherence; Beachey, E.H., Ed.; Springer: Dordrecht, The Netherladns, 1980; pp. 185-217. ISBN 978-94-009-5863-0.

17. Coppa, G.V.; Zampini, L.; Galeazzi, T.; Facinelli, B.; Ferrante, L.; Capretti, R.; Orazio, G. Human Milk Oligosaccharides Inhibit the Adhesion to Caco-2 Cells of Diarrheal Pathogens: Escherichia coli, Vibrio cholerae, and Salmonella fyris. Pediatr. Res. 2006, 59. [CrossRef]

18. Newburg, D.S. Do the binding properties of oligosaccharides in milk protect human infants from gastrointestinal bacteria? J. Nutr. 1997, 127, 980S-984S. [CrossRef]

19. Lin, A.E.; Autran, C.A.; Szyszka, A.; Escajadillo, T.; Huang, M.; Godula, K.; Prudden, A.R.; Boons, G.; Lewis, A.L.; Doran, K.S.; et al. Human milk oligosaccharides inhibit growth of group B. J. Biol. Chem. 2017, 292, 11243-11249. [CrossRef]

20. Andreas, N.J.; Al-Khalidi, A.; Jaiteh, M.; Clarke, E.; Hyde, M.J.; Modi, N.; Holmes, E.; Kampmann, B.; Mehring Le Doare, K. Role of human milk oligosaccharides in Group B Streptococcus colonisation. Clin. Transl. Immunol. 2016, 5, e99. [CrossRef]

21. Ackerman, D.L.; Doster, R.S.; Weitkamp, J.; Aronoff, D.M.; Gaddy, J.A.; Townsend, S.D. Human Milk Oligosaccharides Exhibit Antimicrobial and Antibio film Properties against Group B Streptococcus. ACS Infect. Dis. 2017. [CrossRef]

22. Patel, S.; Goyal, A. Functional Oligosaccharides: Production, Properties and Applications. World J. Microbiol. Biotechnol. 2011, 27. [CrossRef]

23. Smilowitz, J.T.; Lebrilla, C.B.; Mills, D.A.; German, J.B.; Freeman, S.L. Breast Milk Oligosaccharides: Structure-Function Relationships in the Neonate. Annu. Rev. Nutr. 2014, 34, 143-169. [CrossRef]

24. Wicinski, M.; Sawicka, E.; Gebalski, J.; Kubiak, K.; Malinowski, B. Human Milk Oligosaccharides: Health Benefits, Potential Applications in Infant Formulas, and Pharmacology. Nutrients 2020, 12, 266. [CrossRef] [PubMed]

25. Bode, L. Human milk oligosaccharides: Every baby needs a sugar mama. Glycobiology 2012, 22, 1147-1162. [CrossRef] [PubMed]

26. Craft, K.M.; Townsend, S.D. Mother Knows Best: Deciphering the Antibacterial Properties of Human Milk Oligosaccharides. Acc. Chem. Res. 2019, 52, 760-768. [CrossRef]

27. Martín-Sosa, S.; Martín, M.-J.; Hueso, P. The sialylated fraction of milk oligosaccharides is partially responsible for binding to enterotoxigenic and uropathogenic Escherichia coli human strains. J. Nutr. 2002, 132, 3067-3072. [CrossRef]

28. Coppa, G.V.; Gabrielli, O.; Giorgi, P.; Catassi, C.; Montanari, M.P.; Varaldo, P.E.; Nichols, B.L. Preliminary study of breastfeeding and bacterial adhesion to uroepithelial cells. Lancet 1990, 335, 569-571. [CrossRef]

29. Andersson, B.; Porras, O.; Hanson, L.A.; Lagergfird, T.; Svanborg-Eden, C. Inhibition of Attachment of Streptococcus pneumoniae and Haemophilus influenzae by Human Milk and Receptor Oligosaccharides. J. Infect. Dis. 1986, 153, 232-237. [CrossRef] [PubMed]

30. Pham, T.A.N.; Clare, S.; Goulding, D.; Arasteh, J.M.; Stares, M.D.; Browne, H.P.; Keane, J.A.; Page, A.J.; Kumasaka, N.; Kane, L.; et al. Epithelial IL-22RA1-mediated fucosylation promotes intestinal colonization resistance to an opportunistic pathogen. Cell Host Microbe 2014, 16, 504-516. [CrossRef] 
31. Asahara, T.; Takahashi, A.; Yuki, N.; Kaji, R.; Takahashi, T.; Nomoto, K. Protective effect of a synbiotic against multidrug-resistant Acinetobacter baumannii in a murine infection model. Antimicrob. Agents Chemother. 2016, 60, 3041-3050. [CrossRef]

32. Goto, Y.; Obata, T.; Kunisawa, J.; Sato, S.; Ivanov, I.I.; Lamichhane, A.; Takeyama, N.; Kamioka, M.; Sakamoto, M.; Matsuki, T.; et al. Innate lymphoid cells regulate intestinal epithelial cell glycosylation. Science 2014, 345. [CrossRef] [PubMed]

33. Newburg, D.S.; Ruiz-Palacios, G.M.; Morrow, A.L. Human Milk Glycans Protect Infants Against Enteric Pathogens. Annu. Rev. Nutr. 2005, 25, 37-58. [CrossRef] [PubMed]

34. Cravioto, A.; Tello, A.; Villafán, H.; Ruiz, J.; del Vedovo, S.; Neeser, J.-R. Inhibition of Localized Adhesion of Enteropathogenic Escherichia coli to HEp-2 Cells by Immunoglobulin and Oligosaccharide Fractions of Human Colostrum and Breast Milk. J. Infect. Dis. 1991, 163, 1247-1255. [CrossRef] [PubMed]

35. Hakkarainen, J.; Toivanen, M.; Leinonen, A.; Frängsmyr, L.; Strömberg, N.; Lapinjoki, S.; Nassif, X.; Tikkanen-Kaukanen, C. Human and Bovine Milk Oligosaccharides Inhibit Neisseria meningitidis Pili Attachment In Vitro. J. Nutr. 2005, 135, 2445-2448. [CrossRef]

36. Kobata, A. Structures and application of oligosaccharides in human milk. Proc. Jpn. Acad. Ser. Phys. Biol. Sci. 2010, 86, 731-747. [CrossRef]

37. Craft, K.M.; Gaddy, J.A.; Townsend, S.D. Human Milk Oligosaccharides (HMOs) Sensitize Group B Streptococcus to Clindamycin, Erythromycin, Gentamicin, and Minocycline on a Strain Specific Basis. ACS Chem. Biol. 2018, 13, 2020-2026. [CrossRef]

38. Hsuchen, C.C.; Feingold, D.S. The Mechanism of Polymyxin B Action and Selectivity toward Biologic Membranes. Biochemistry 1973, 12, 2105-2111. [CrossRef]

39. Lin, A.E.; Autran, C.A.; Espanola, S.D.; Bode, L.; Nizet, V. Human milk oligosaccharides protect bladder epithelial cells against uropathogenic escherichia coli invasion and cytotoxicity. J. Infect. Dis. 2014, 209, 389-398. [CrossRef]

40. Turner, C.E. Paxillin and focal adhesion signalling. Nat. Cell Biol. 2000, 2, 231-236. [CrossRef]

41. Schumacher, G.; Bendas, G.; Stahl, B.; Beermann, C. Human milk oligosaccharides affect P-selectin binding capacities: In vitro investigation. Nutrition 2006, 22, 620-627. [CrossRef]

42. Craft, K.M.; Thomas, H.C.; Townsend, S.D. Interrogation of Human Milk Oligosaccharide Fucosylation Patterns for Antimicrobial and Antibiofilm Trends in Group B Streptococcus. ACS Infect. Dis. 2018, 4, 1755-1765. [CrossRef] [PubMed]

43. Ackerman, D.L.; Craft, K.M.; Doster, R.S.; Weitkamp, J.H.; Aronoff, D.M.; Gaddy, J.A.; Townsend, S.D. Antimicrobial and Antibiofilm Activity of Human Milk Oligosaccharides against Streptococcus agalactiae, Staphylococcus aureus, and Acinetobacter baumannii. ACS Infect. Dis. 2018, 4, 315-324. [CrossRef] [PubMed]

44. Craft, K.M.; Thomas, H.C.; Townsend, S.D. Sialylated variants of lacto-: N-tetraose exhibit antimicrobial activity against Group B Streptococcus. Org. Biomol. Chem. 2019, 17, 1893-1900. [CrossRef] [PubMed]

45. Bode, L.; Jantscher-Krenn, E. Structure-function relationships of human milk oligosaccharides. Adv. Nutr. 2012, 3, 383S-391S. [CrossRef] [PubMed]

46. Ruiz-Palacios, G.M.; Cervantes, L.E.; Ramos, P.; Chavez-Munguia, B.; Newburg, D.S. Campylobacter jejuni binds intestinal $\mathrm{H}(\mathrm{O})$ antigen (Fuc alpha 1, $2 \mathrm{Gal}$ beta 1, 4GlcNAc), and fucosyloligosaccharides of human milk inhibit its binding and infection. J. Biol. Chem. 2003, 278, 14112-14120. [CrossRef] [PubMed]

47. Weichert, S.; Jennewein, S.; Hufner, E.; Weiss, C.; Borkowski, J.; Putze, J.; Schroten, H. Bioengineered 2 -fucosyllactose and 3-fucosyllactose inhibit the adhesion of Pseudomonas aeruginosa and enteric pathogens to human intestinal and respiratory cell lines. Nutr. Res. 2013, 33, 831-838. [CrossRef] [PubMed]

48. Obermeier, S.; Rudloff, S.; Pohlentz, G.; Lentze, M.J.; Kunz, C. Secretion of 13C-labelled oligosaccharides into human milk and infant's urine after an oral [13C]galactose load. Isotopes Environ. Health Stud. 1999, 35, 119-125. [CrossRef] [PubMed]

49. Craft, K.M.; Townsend, S.D. 1-Amino-2'-fucosyllactose inhibits biofilm formation by Streptococcus agalactiae. J. Antibiot. Tokyo 2019, 72, 507-512. [CrossRef]

50. Thurl, S.; Munzert, M.; Boehm, G.; Matthews, C.; Stahl, B. Systematic review of the concentrations of oligosaccharides in human milk. Nutr. Rev. 2017, 75, 920-933. [CrossRef] 
51. Ninonuevo, M.R.; Park, Y.; Yin, H.; Zhang, J.; Ward, R.E.; Clowers, B.H.; German, J.B.; Freeman, S.L.; Killeen, K.; Grimm, R.; et al. A strategy for annotating the human milk glycome. J. Agric. Food Chem. 2006, 54, 7471-7480. [CrossRef]

52. Marotta, M.; Ryan, J.T.; Hickey, R.M. The predominant milk oligosaccharide 6 '-sialyllactose reduces the internalisation of Pseudomonas aeruginosa in human pneumocytes. J. Funct. Foods 2014, 6, 367-373. [CrossRef]

53. Lee, J.M.; Oh, S.Y.; Johnston, T.V.; Ku, S.; Ji, G.E. Biocatalysis of fucodian in undaria pinnatifida sporophyll using bifidobacterium longum rd47 for production of prebiotic fucosylated oligosaccharide. Mar. Drugs 2019, 17, 117. [CrossRef] [PubMed]

54. Fitton, J.H. Therapies from fucoidan; multifunctional marine polymers. Mar. Drugs 2011, 9, 1731-1760. [CrossRef] [PubMed]

55. Hanisch, F.G.; Hansman, G.S.; Morozov, V.; Kunz, C.; Schroten, H. Avidity of -fucose on human milk oligosaccharides and blood group-unrelated oligo/polyfucoses is essential for potent norovirus-binding targets. J. Biol. Chem. 2018, 293, 11955-11965. [CrossRef]

56. Newburg, D.S.; Ruiz-Palacios, G.M.; Altaye, M.; Chaturvedi, P.; Meinzen-Derr, J.; de Lourdes Guerrero, M.; Morrow, A.L. Innate protection conferred by fucosylated oligosaccharides of human milk against diarrhea in breastfed infants. Glycobiology 2004, 14, 253-263. [CrossRef]

57. Rehm, B.H.A. Bacterial polymers: Biosynthesis, modifications and applications. Nat. Rev. Microbiol. 2010, 8, 578. [CrossRef]

58. Lattner, D.; Flemming, H.-C.; Mayer, C. 13C-NMR study of the interaction of bacterial alginate with bivalent cations. Int. J. Biol. Macromol. 2003, 33, 81-88. [CrossRef]

59. Skjåk-Bræk, G.; Grasdalen, H.; Larsen, B. Monomer sequence and acetylation pattern in some bacterial alginates. Carbohydr. Res. 1986, 154, 239-250. [CrossRef]

60. Remminghorst, U.; Rehm, B.H.A. Bacterial alginates: From biosynthesis to applications. Biotechnol. Lett. 2006, 28, 1701-1712. [CrossRef]

61. Schurks, N.; Wingender, J.; Flemming, H.-C.; Mayer, C. Monomer composition and sequence of alginates from Pseudomonas aeruginosa. Int. J. Biol. Macromol. 2002, 30, 105-111. [CrossRef]

62. Overhage, J.; Lewenza, S.; Marr, A.K.; Hancock, R.E.W. Identification of genes involved in swarming motility using a Pseudomonas aeruginosa PAO1 mini-Tn5-lux mutant library. J. Bacteriol. 2007, 189, 2164-2169. [CrossRef] [PubMed]

63. Khan, S.; Tøndervik, A.; Sletta, H.; Klinkenberg, G.; Emanuel, C.; Onsøyen, E.; Myrvold, R. Overcoming Drug Resistance with Alginate Oligosaccharides Able To Potentiate the Action of Selected Antibiotics. Antimicrob. Agents Chemother. 2012, 56, 5134-5141. [CrossRef] [PubMed]

64. Powell, L.C.; Sowedan, A.; Khan, S.; Wright, C.J.; Onsøyen, E.; Myrvold, R.; Hill, K.E.; Thomas, D.W. The effect of alginate oligosaccharides on the mechanical properties of Gram-negative biofilms. Biofouling 2013, 7014. [CrossRef] [PubMed]

65. Powell, L.C.; Pritchard, M.F.; Emanuel, C.; Onsøyen, E.; Rye, P.D.; Wright, C.J.; Hill, K.E.; Thomas, D.W. Original Research: A Nanoscale Characterization of the Interaction of a Novel Alginate Oligomer with the Cell Surface and Motility of Pseudomonas aeruginosa. Am. J. Respir. Cell Mol. Biol. 2014, 50, 483-492. [CrossRef]

66. Pritchard, M.F.; Powell, L.C.; Jack, A.A.; Powell, K.; Beck, K.; Florance, H.; Forton, J.; Rye, P.D.; Dessen, A.; Hill, K.E.; et al. A Low-Molecular-Weight Alginate Oligosaccharide Disrupts Pseudomonal Microcolony Formation and Enhances Antibiotic Effectiveness. Antimicrob. Agents Chemother. 2017, 61, 1-14. [CrossRef]

67. Pritchard, M.F.; Powell, L.C.; Khan, S.; Griffiths, P.C.; Mansour, O.T.; Schweins, R.; Beck, K.; Buurma, N.J.; Dempsey, C.E.; Wright, C.J.; et al. The antimicrobial effects of the alginate oligomer OligoG CF-5/20 are independent of direct bacterial cell membrane disruption. Sci. Rep. 2017, 7. [CrossRef]

68. Overhage, J.; Bains, M.; Brazas, M.D.; Hancock, R.E.W. Swarming of Pseudomonas aeruginosa is a complex adaptation leading to increased production of virulence factors and antibiotic resistance. J. Bacteriol. 2008, 190, 2671-2679. [CrossRef]

69. Powell, L.C.; Pritchard, M.F.; Ferguson, E.L.; Powell, K.A.; Patel, S.U.; Rye, P.D.; Sakellakou, S.-M.; Buurma, N.J.; Brilliant, C.D.; Copping, J.M.; et al. Targeted disruption of the extracellular polymeric network of Pseudomonas aeruginosa biofilms by alginate oligosaccharides. NPJ Biofilms Microbiomes 2018, 4. [CrossRef] 
70. Roberts, J.L.; Khan, S.; Emanuel, C.; Powell, L.C.; Pritchard, M.F.; Onsoyen, E.; Myrvold, R.; Thomas, D.W.; Hill, K.E. An in vitro study of alginate oligomer therapies on oral biofilms. J. Dent. 2013, 41, 892-899. [CrossRef]

71. Korstgens, V.; Flemming, H.C.; Wingender, J.; Borchard, W. Influence of calcium ions on the mechanical properties of a model biofilm of mucoid Pseudomonas aeruginosa. Water Sci. Technol. 2001, 43, 49-57. [CrossRef]

72. Aslam, S.N.; Newman, M.-A.; Erbs, G.; Morrissey, K.L.; Chinchilla, D.; Boller, T.; Jensen, T.T.; De Castro, C.; Ierano, T.; Molinaro, A.; et al. Bacterial polysaccharides suppress induced innate immunity by calcium chelation. Curr. Biol. 2008, 18, 1078-1083. [CrossRef] [PubMed]

73. Pier, G.B.; Coleman, F.; Grout, M.; Franklin, M.; Ohman, D.E. Role of Alginate O Acetylation in Resistance of Mucoid Pseudomonas aeruginosa to Opsonic Phagocytosis. Infect. Immun. 2001, 69, 1895-1901. [CrossRef] [PubMed]

74. Nivens, D.E.; Ohman, D.E.; Williams, J.; Franklin, M.J. Role of alginate and its O acetylation in formation of Pseudomonas aeruginosa microcolonies and biofilms. J. Bacteriol. 2001, 183, 1047-1057. [CrossRef] [PubMed]

75. Sarkisova, S.; Patrauchan, M.A.; Berglund, D.; Nivens, D.E.; Franklin, M.J. Calcium-induced virulence factors associated with the extracellular matrix of mucoid Pseudomonas aeruginosa biofilms. J. Bacteriol. 2005, 187, 4327-4337. [CrossRef] [PubMed]

76. Banin, E.; Vasil, M.L.; Greenberg, E.P. Iron and Pseudomonas aeruginosa biofilm formation. Proc. Natl. Acad. Sci. USA 2005, 102, 11076-11081. [CrossRef]

77. Wiens, J.R.; Vasil, A.I.; Schurr, M.J.; Vasil, M.L. Iron-regulated expression of alginate production, mucoid phenotype, and biofilm formation by Pseudomonas aeruginosa. MBio 2014, 5, e01010-e1013. [CrossRef]

78. Falkeborg, M.; Cheong, L.-Z.; Gianfico, C.; Sztukiel, K.M.; Kristensen, K.; Glasius, M.; Xu, X.; Guo, Z. Alginate oligosaccharides: Enzymatic preparation and antioxidant property evaluation. Food Chem. 2014, 164, 185-194. [CrossRef]

79. Jiang, Q.; Chen, J.; Yang, C.; Yin, Y.; Yao, K.; Song, D. Quorum Sensing: A Prospective Therapeutic Target for Bacterial Diseases. Biomed. Res. Int. 2019, 2019. [CrossRef]

80. Williams, P.; Cámara, M. Quorum sensing and environmental adaptation in Pseudomonas aeruginosa: A tale of regulatory networks and multifunctional signal molecules. Curr. Opin. Microbiol. 2009, 12, 182-191. [CrossRef]

81. Allesen-Holm, M.; Barken, K.B.; Yang, L.; Klausen, M.; Webb, J.S.; Kjelleberg, S.; Molin, S.; Givskov, M.; Tolker-Nielsen, T. A characterization of DNA release in Pseudomonas aeruginosa cultures and biofilms. Mol. Microbiol. 2006, 59, 1114-1128. [CrossRef]

82. Yang, L.; Barken, K.B.; Skindersoe, M.E.; Christensen, A.B.; Givskov, M.; Tolker-Nielsen, T. Effects of iron on DNA release and biofilm development by Pseudomonas aeruginosa. Microbiology 2007, 153, 1318-1328. [CrossRef] [PubMed]

83. Whitchurch, C.B.; Tolker-Nielsen, T.; Ragas, P.C.; Mattick, J.S. Extracellular DNA required for bacterial biofilm formation. Science 2002, 295, 1487. [CrossRef]

84. Jack, A.A.; Khan, S.; Powell, L.C.; Pritchard, M.F.; Beck, K.; Sadh, H.; Sutton, L.; Cavaliere, A.; Florance, H.; Rye, P.D.; et al. Alginate oligosaccharide-induced modification of the lasI-lasR and rhlI-rhlR quorum-sensing systems in pseudomonas aeruginosa. Antimicrob. Agents Chemother. 2018, 62. [CrossRef] [PubMed]

85. Phillips, P.L.; Schultz, G.S. Molecular Mechanisms of Biofilm Infection: Biofilm Virulence Factors. Adv. Wound Care 2012, 1, 109-114. [CrossRef]

86. Das, T.; Manefield, M. Pyocyanin Promotes Extracellular DNA Release in Pseudomonas aeruginosa. PLOS ONE 2012, 7, e46718. [CrossRef]

87. Elkins, J.G.; Hassett, D.J.; Stewart, P.S.; Schweizer, H.P.; McDermott, T.R. Protective role of catalase in Pseudomonas aeruginosa biofilm resistance to hydrogen peroxide. Appl. Environ. Microbiol. 1999, 65, 4594-4600. [CrossRef]

88. He, X.; Hwang, H.; Aker, W.G.; Wang, P.; Lin, Y.; Jiang, X.; He, X.; Sim, C.O.S. Synergistic combination of marine oligosaccharides and azithromycin against Pseudomonas aeruginosa. Microbiol. Res. 2014, 169, 759-767. [CrossRef]

89. Jollès, P.; Muzzarelli, R.A.A. Chitin and Chitinases; Birkhäuser Verlag: Basel, Switzerland, 1999. ISBN 978376-435-8150. 
90. Liaqat, F.; Eltem, R. Chitooligosaccharides and their biological activities: A comprehensive review. Carbohydr. Polym. 2018, 184, 243-259. [CrossRef]

91. Lodhi, G.; Kim, Y.-S.; Hwang, J.-W.; Kim, S.-K.; Jeon, Y.-J.; Je, J.-Y.; Ahn, C.-B.; Moon, S.-H.; Jeon, B.-T.; Park, P.-J. Chitooligosaccharide and its derivatives: Preparation and biological applications. Biomed. Res. Int. 2014, 2014, 654913. [CrossRef]

92. Mourya, V.K.; Inamdar, N.N.; Choudhari, Y.M. Chitooligosaccharides: Synthesis, characterization and applications. Polym. Sci. Ser. A 2011, 53, 583-612. [CrossRef]

93. Kyoon, H.; Young, N.; Ho, S.; Meyers, S.P. Antibacterial activity of chitosans and chitosan oligomers with different molecular weights. Int. J. Food Microbiol. 2002, 74, 65-72.

94. Zheng, L.-Y.; Zhu, J.-F. Study on antimicrobial activity of chitosan with different molecular weights. Carbohydr. Polym. 2003, 54, 527-530. [CrossRef]

95. Fernandes, J.C.; Tavaria, F.K.; Soares, J.C.; Ramos, O.S.; João Monteiro, M.; Pintado, M.E.; Xavier Malcata, F. Antimicrobial effects of chitosans and chitooligosaccharides, upon Staphylococcus aureus and Escherichia coli, in food model systems. Food Microbiol. 2008, 25, 922-928. [CrossRef]

96. Kim, S.-K.; Rajapakse, N. Enzymatic production and biological activities of chitosan oligosaccharides (COS): A review. Carbohydr. Polym. 2005, 62, 357-368. [CrossRef]

97. Kurita, K.; Kaji, Y.; Mori, T.; Nishiyama, Y. Enzymatic degradation of $\beta$-chitin: Susceptibility and the influence of deacetylation. Carbohydr. Polym. 2000, 42, 19-21. [CrossRef]

98. Riegman, N.; Kusters, R.; Van Veggel, H.; Bergmans, H.; Van Bergen en Henegouwen, P.; Hacker, J.; Van Die, I. F1C fimbriae of a uropathogenic Escherichia coli strain: Genetic and functional organization of the foc gene cluster and identification of minor subunits. J. Bacteriol. 1990, 172, 1114-1120. [CrossRef] [PubMed]

99. Kim, S.K.; Park, P.J.; Yang, H.P.; Han, S.S. Subacute toxicity of chitosan oligosaccharide in Sprague-Dawley rats. Arzneimittelforschung 2001, 51, 769-774. [CrossRef]

100. VandeVord, P.J.; Matthew, H.W.T.; DeSilva, S.P.; Mayton, L.; Wu, B.; Wooley, P.H. Evaluation of the biocompatibility of a chitosan scaffold in mice. J. Biomed. Mater. Res. 2002, 59, 585-590. [CrossRef]

101. Allan, C.R.; Hadwiger, L.A. The fungicidal effect of chitosan on fungi of varying cell wall composition. Exp. Mycol. 1979, 3, 285-287. [CrossRef]

102. Choi, B.; Kim, K.; Yoo, Y.; Oh, S. In vitro antimicrobial activity of a chitooligosaccharide mixture against Actinobacillus actinomycetemcomitans and Streptococcus mutans. Int. J. Antimicrob. Agents 2001, 18, 553-557. [CrossRef]

103. Sanchez, A.; Mengibar, M.; Rivera-Rodriguez, G.; Moerchbacher, B.; Acosta, N.; Heras, A. The effect of preparation processes on the physicochemical characteristics and antibacterial activity of chitooligosaccharides. Carbohydr. Polym. 2017, 157, 251-257. [CrossRef] [PubMed]

104. Fernandes, J.C.; Tavaria, F.K.; Fonseca, S.C.; Ramos, O.S.; Pintado, M.E.; Malcata, F.X. In vitro screening for anti-microbial activity of chitosans and chitooligosaccharides, aiming at potential uses in functional textiles. J. Microbiol. Biotechnol. 2010, 20, 311-318. [CrossRef] [PubMed]

105. Jeon, Y.; Park, P.; Kim, S. Antimicrobial effect of chitooligosaccharides produced by bioreactor. Carbohydr. Polym. 2001, 44, 71-76. [CrossRef]

106. Helander, I.M.; Latva-Kala, K.; Lounatmaa, K. Permeabilizing action of polyethyleneimine on Salmonella typhimurium involves disruption of the outer membrane and interactions with lipopolysaccharide. Microbiology 1998, 144, 385-390. [CrossRef]

107. Demeneix, B.; Behr, J.B.T.-A. Polyethylenimine (PEI). In Non-Viral Vectors for Gene Therapy, 2nd ed.; Academic Press: San Diego, CA, USA, 2005; Volume 53, pp. 215-230. ISBN 0120176548.

108. Vancha, A.R.; Govindaraju, S.; Parsa, K.V.L.; Jasti, M.; González-García, M.; Ballestero, R.P. Use of polyethyleneimine polymer in cell culture as attachment factor and lipofection enhancer. BMC Biotechnol. 2004, 4, 23. [CrossRef] [PubMed]

109. Helander, I.M.; Nurmiaho-Lassila, E.L.; Ahvenainen, R.; Rhoades, J.; Roller, S. Chitosan disrupts the barrier properties of the outer membrane of gram-negative bacteria. Int. J. Food Microbiol. 2001, 71, 235-244. [CrossRef]

110. Young, D.H.; Kohle, H.; Kauss, H. Effect of Chitosan on Membrane Permeability of Suspension-Cultured Glycine max and Phaseolus vulgaris Cells. Plant Physiol. 1982, 70, 1449-1454. [CrossRef] 
111. Young, D.H.; Kauss, H. Release of Calcium from Suspension-Cultured Glycine max Cells by Chitosan, Other Polycations, and Polyamines in Relation to Effects on Membrane Permeability. Plant Physiol. 1983, 73, 698-702. [CrossRef]

112. Kumar, A.B.V.; Varadaraj, M.C.; Gowda, L.R.; Tharanathan, R.N. Characterization of chito-oligosaccharides prepared by chitosanolysis with the aid of papain and Pronase, and their bactericidal action against Bacillus cereus and Escherichia coli. Biochem. J. 2005, 175, 167-175.

113. Moon, J.-S.; Kim, H.-K.; Koo, H.C.; Joo, Y.-S.; Nam, H.; Park, Y.H.; Kang, M.-I. The antibacterial and immunostimulative effect of chitosan-oligosaccharides against infection by Staphylococcus aureus isolated from bovine mastitis. Appl. Microbiol. Biotechnol. 2007, 75, 989-998. [CrossRef]

114. Benhabiles, M.S.; Salah, R.; Lounici, H.; Drouiche, N.; Goosen, M.F.A.; Mameri, N. Food Hydrocolloids Antibacterial activity of chitin, chitosan and its oligomers prepared from shrimp shell waste. Food Hydrocoll. 2012, 29, 48-56. [CrossRef]

115. Quintero-villegas, M.I.; Aam, B.B.; Rupnow, J.; Sørlie, M.; Eijsink, V.G.H.; Hutkins, R.W. Adherence Inhibition of Enteropathogenic Escherichia coli by Chitooligosaccharides with Speci fi c Degrees of Acetylation and Polymerization. Agric. Food Chem. 2013, 61, 2748-2754. [CrossRef] [PubMed]

116. Rhoades, J.; Gibson, G.; Formentin, K.; Beer, M.; Rastall, R. Inhibition of the adhesion of enteropathogenic Escherichia coli strains to HT-29 cells in culture by chito-oligosaccharides. Carbohydr. Polym. 2006, 64, 57-59. [CrossRef]

117. Hadwiger, L.A.; Beckman, J.M. Chitosan as a Component of Pea-Fusarium solani Interactions. Plant Physiol. 1980, 66, 205-211. [CrossRef] [PubMed]

118. Li, X.-F.; Feng, X.-Q.; Yang, S.; Wang, T.-P.; Su, Z.-X. Effects of molecular weight and concentration of chitosan on antifungal activity against aspergillus niger. Iran. Polym. J. Engl. Ed. 2008, 17, 843-852.

119. Sebti, I.; Martial-Gros, A.; Carnet-Pantiez, A.; Grelier, S.; Coma, V. Chitosan Polymer as Bioactive Coating and Film against Aspergillus niger Contamination. J. Food Sci. 2005, 70, M100-M104. [CrossRef]

120. Wagoner, W.; Loschke, D.C.; Hadwiger, L.A. Two-dimensional electrophoretic analysis of in vivo and in vitro synthesis of proteins in peas inoculated with compatible and incompatible Fusarium solani. Physiol. Plant Pathol. 1982, 99-107. [CrossRef]

121. Liu, X.F.; Lin Guan, Y.; Zhi Yang, D.; Li, Z.; De Yao, K. Antibacterial action of chitosan and carboxymethylated chitosan. J. Appl. Polym. Sci. 2001, 79, 1324-1335.

122. Raafat, D.; Sahl, H.-G. Chitosan and its antimicrobial potential-A critical literature survey. Microb. Biotechnol. 2009, 2, 186-201. [CrossRef]

123. Nikaido, H. Multidrug resistance in bacteria. Annu. Rev. Biochem. 2009, 78, 119-146. [CrossRef]

124. Tin, S.; Sing Lim, C.; Sakharkar, M.; Ramaji Sakharkar, K. Synergistic Combinations of Chitosans and Antibiotics in Staphylococcus Aureus; Bentham Science Publishers: Sharjah, UAE, 2010; Volume 7.

125. Tin, S.; Sakharkar, K.R.; Lim, C.S.; Sakharkar, M.K. Activity of Chitosans in combination with antibiotics in Pseudomonas aeruginosa. Int. J. Biol. Sci. 2009, 5, 153-160. [CrossRef] [PubMed]

126. Jeon, Y.; Kim, S. Production of chitooligosaccharides using an ultrafiltration membrane reactor and their antibacterial activity. Carbohydr. Polym. 2000, 41, 133-141. [CrossRef]

127. Lee, B.C.; Kim, S.M.; Choi, S.H.; Kim, K.Y.; Kim, T.S. In vitro and in vivo antimicrobial activity of water-soluble chitosan oligosaccharides against Vibrio vulnificus. Int. J. Mol. Med. 2009, 327-333. [CrossRef]

128. Laokuldilok, T.; Potivas, T.; Kanha, N.; Surawang, S.; Seesuriyachan, P.; Wangtueai, S.; Phimolsiripol, Y.; Regenstein, J.M. Physicochemical, antioxidant, and antimicrobial properties of chitooligosaccharides produced using three different enzyme treatments. Food Biosci. 2017, 18, 28-33. [CrossRef]

129. Roberfroid, M.B. Functional foods: Concepts and application to inulin and oligofructose. Br. J. Nutr. 2002, 87, S139-S143. [CrossRef] [PubMed]

130. Al-Ghazzewi, F.H.; Tester, R.F. Inhibition of the adhesion of Escherichia coli to human epithelial cells by carbohydrates. Bioact. Carbohydr. Diet. Fibre 2014, 4, 1-5. [CrossRef]

131. Kim, J.K.; Shin, E.C.; Park, H.G. Fructooligosaccharides decreased the ability of probiotic Escherichia coli Nissle 1917 to adhere to co-cultures of human intestinal cell lines. J. Korean Soc. Appl. Biol. Chem. 2015, 58, 45-52. [CrossRef]

132. Ortega-González, M.; Sánchez De Medina, F.; Molina-Santiago, C.; López-Posadas, R.; Pacheco, D.; Krell, T.; Martínez-Augustin, O.; Abdelali, D. Fructooligosacharides reduce Pseudomonas aeruginosa PAO1 pathogenicity through distinct mechanisms. PLoS ONE 2014, 9, e85772. [CrossRef] 
133. Intanon, M.; Arreola, S.L.; Pham, N.H.; Kneifel, W.; Haltrich, D.; Nguyen, T.H. Nature and biosynthesis of galacto-oligosaccharides related to oligosaccharides in human breast milk. FEMS Microbiol. Lett. 2014, 353, 89-97. [CrossRef]

134. Rastall, R.A. Functional oligosaccharides: Application and manufacture. Annu. Rev. Food Sci. Technol. 2010, 1, 305-339. [CrossRef]

135. Coulier, L.; Timmermans, J.; Bas, R.; Van Den Dool, R.; Haaksman, I.; Klarenbeek, B.; Slaghek, T.; Van Dongen, W. In-depth characterization of prebiotic galacto-oligosaccharides by a combination of analytical techniques. J. Agric. Food Chem. 2009, 57, 8488-8495. [CrossRef] [PubMed]

136. Petri, W.A., Jr.; Smith, R.D.; Schlesinger, P.H.; Murphy, C.F.; Ravdin, J.I. Isolation of the galactose-binding lectin that mediates the in vitro adherence of Entamoeba histolytica. J. Clin. Investig. 1987, 80, 1238-1244. [CrossRef] [PubMed]

137. Petri, W.A., Jr.; Haque, R.; Mann, B.J. The bittersweet interface of parasite and host: Lectin-carbohydrate interactions during human invasion by the parasite Entamoeba histolytica. Annu. Rev. Microbiol. 2002, 56, 39-64. [CrossRef]

138. Shoaf, K.; Mulvey, G.L.; Armstrong, G.D.; Hutkins, R.W. Prebiotic Galactooligosaccharides Reduce Adherence of Enteropathogenic Escherichia coli to Tissue Culture Cells. Infect. Immun. 2006, 74, 6920-6928. [CrossRef]

139. Searle, L.E.J.; Cooley, W.A.; Jones, G.; Nunez, A.; Crudgington, B.; Weyer, U.; Dugdale, A.H.; Tzortzis, G.; Collins, J.W.; Woodward, M.J.; et al. Purified galactooligosaccharide, derived from a mixture produced by the enzymic activity of Bifidobacterium bifidum, reduces Salmonella enterica serovar Typhimurium adhesion and invasion in vitro and in vivo. J. Med. Microbiol. 2010, 1428-1439. [CrossRef]

140. Kittana, H.; Quintero-Villegas, M.I.; Bindels, L.B.; Gomes-Neto, J.C.; Schmaltz, R.J.; Segura Munoz, R.R.; Cody, L.A.; Moxley, R.A.; Hostetter, J.; Hutkins, R.W.; et al. Galactooligosaccharide supplementation provides protection against citrobacter rodentium-induced colitis without limiting pathogen burden. Microbiology UK 2018, 164, 154-162. [CrossRef] [PubMed]

141. Ebersbach, T.; Bo, J.; Bergstro, A.; Hutkins, R.W.; Rask, T. Xylo-oligosaccharides inhibit pathogen adhesion to enterocytes in vitro. Res. Microbiol. 2012, 163, 22-27. [CrossRef]

142. Quintero, M.; Maldonado, M.; Perez-Munoz, M.; Jimenez, R.; Fangman, T.; Rupnow, J.; Wittke, A.; Russell, M.; Hutkins, R. Adherence inhibition of Cronobacter sakazakii to intestinal epithelial cells by prebiotic oligosaccharides. Curr. Microbiol. 2011, 62, 1448-1454. [CrossRef]

143. Mange, J.; Stephan, R.; Borel, N.; Wild, P.; Kim, K.S.; Pospischil, A.; Lehner, A. Adhesive properties of Enterobacter sakazakii to human epithelial and brain microvascular endothelial cells. BMC Microbiol. 2006, 10. [CrossRef]

144. Muanprasat, C.; Chatsudthipong, V. Cholera: Pathophysiology and emerging therapeutic targets. Future Med. Chem. 2013, 5, 781-798. [CrossRef]

145. Lanne, B.; Ångstrom, J.; Schierbeck, B. Binding of Cholera Toxin B-Subunits to Derivatives of the Natural Ganglioside Receptor, GM1. J. Biochem. 1999, 126, 226-234. [CrossRef] [PubMed]

146. Wallenfels, K.; Malhotra, O.P. Galactosidases. Adv. Carbohydr. Chem. 1962, 16, 239-298.

147. Holmgren, J. Actions of cholera toxin and the prevention and treatment of cholera. Nature 1981, 292, $413-417$. [CrossRef]

148. Haksar, D.; Pieters, R.J. A hybrid polymer to target blood group dependence of cholera toxin. Org. Biomol. Chem. 2020, 18, 52-55. [CrossRef] [PubMed]

149. Sinclair, H.R.; De Slegte, J.; Gibson, G.R.; Rastall, R.A. Galactooligosaccharides (GOS) inhibit vibrio cholerae toxin binding to its GM1 receptor. J. Agric. Food Chem. 2009, 57, 3113-3119. [CrossRef] [PubMed]

150. Ommen, D.D.Z.; Pukin, A.V.; Fu, O.; Quarles, L.H.C.; Van, U.; Janssens, H.M.; Beekman, M.; Pieters, R.J. Functional Characterization of Cholera Toxin Inhibitors Using Human Intestinal Organoids. J. Med. Chem. 2016, 59, 6968-6972. [CrossRef]

151. Ofek, I.; Beachey, E.H. Mannose binding and epithelial cell adherence of Escherichia coli. Infect. Immun. 1978, 22, 247-254. [CrossRef]

152. Ofek, I.; Mirelman, D.; Sharon, N. Adherence of Escherichia coli to human mucosal cells mediated by mannose receptors. Nature 1977, 265, 623-625. [CrossRef]

153. Firon, N.; Ofek, I.; Sharon, N. Carbohydrate specificity of the surface lectins of Escherichia coli, Klebsiella pneumoniae, and Salmonella typhimurium. Carbohydr. Res. 1983, 120, 235-249. [CrossRef] 
154. Liu, X.-Y.; Wang, Q.; Cui, S.W.; Liu, H.-Z. A new isolation method of $\beta$-d-glucans from spent yeast Saccharomyces cerevisiae. Food Hydrocoll. 2008, 22, 239-247. [CrossRef]

155. Jones, C.H.; Pinkner, J.S.; Roth, R.; Heuser, J.; Nicholes, A.V.; Abraham, S.N.; Hultgren, S.J. FimH adhesin of type 1 pili is assembled into a fibrillar tip structure in the Enterobacteriaceae. Proc. Natl. Acad. Sci. USA 1995, 92, 2081-2085. [CrossRef] [PubMed]

156. Krogfelt, K.A.; Bergmans, H.; Klemm, P. Direct evidence that the FimH protein is the mannose-specific adhesin of Escherichia coli type 1 fimbriae. Infect. Immun. 1990, 58, 1995-1998. [CrossRef] [PubMed]

157. Firon, N.; Ofek, I.; Sharon, N. Carbohydrate-binding sites of the mannose-specific fimbrial lectins of enterobacteria. Infect. Immun. 1984, 43, 1088-1090. [CrossRef] [PubMed]

158. Firon, N.; Ashkenazi, S.; Mirelman, D.; Ofek, I.; Sharon, N. Aromatic alpha-glycosides of mannose are powerful inhibitors of the adherence of type 1 fimbriated Escherichia coli to yeast and intestinal epithelial cells. Infect. Immun. 1987, 55, 472-476. [CrossRef]

159. Lindhorst, T.K.; Kieburg, C.; Krallmann-Wenzel, U. Inhibition of the type 1 fimbriae-mediated adhesion of Escherichia coli to erythrocytes by multiantennary alpha-mannosyl clusters: The effect of multivalency. Glycoconj. J. 1998, 15, 605-613. [CrossRef]

160. Bouckaert, J.; Mackenzie, J.; De Paz, J.L.; Chipwaza, B.; Choudhury, D.; Zavialov, A.; Mannerstedt, K.; Anderson, J.; Piérard, D.; Wyns, L.; et al. The affinity of the FimH fimbrial adhesin is receptor-driven and quasi-independent of Escherichia coli pathotypes. Mol. Microbiol. 2006, 61, 1556-1568. [CrossRef]

161. Rosen, D.A.; Pinkner, J.S.; Walker, J.N.; Elam, J.S.; Jones, J.M.; Hultgren, S.J. Molecular variations in Klebsiella pneumoniae and Escherichia coli FimH affect function and pathogenesis in the urinary tract. Infect. Immun. 2008, 76, 3346-3356. [CrossRef]

162. Sokurenko, E.V.; Chesnokova, V.; Dykhuizen, D.E.; Ofek, I.; Wu, X.R.; Krogfelt, K.A.; Struve, C.; Schembri, M.A.; Hasty, D.L. Pathogenic adaptation of Escherichia coli by natural variation of the FimH adhesin. Proc. Natl. Acad. Sci. USA 1998, 95, 8922-8926. [CrossRef]

163. Ramirez-Hernandez, A.; Rupnow, J.; Hutkins, R.W. Adherence reduction of campylobacter jejuni and campylobacter coli strains to HEp-2 cells by mannan oligosaccharides and a high-molecular-weight component of cranberry extract. J. Food Prot. 2015, 78, 1496-1505. [CrossRef]

164. Ganner, A.; Schatzmayr, G. Capability of yeast derivatives to adhere enteropathogenic bacteria and to modulate cells of the innate immune system. Appl. Microbiol. Biotechnol. 2012, 95, 289-297. [CrossRef]

165. Ganner, A.; Stoiber, C.; Uhlik, J.T.; Dohnal, I.; Schatzmayr, G. Quantitative evaluation of E. coli F4 and Salmonella Typhimurium binding capacity of yeast derivatives. AMB Express 2013, 3, 62. [CrossRef] [PubMed]

166. Xu, X.; Qiao, Y.; Peng, Q.; Gao, L.; Shi, B. Inhibitory effects of YCW and MOS from Saccharomyces cerevisiae on Escherichia coli and Salmonella pullorum adhesion to Caco-2 cells. Front. Biol. Beijing 2017, 12, 370-375. [CrossRef]

167. Firon, N.; Ofek, I.; Sharon, N. Interaction of mannose-containing oligosaccharides with the fimbrial lectin of Escherichia coli. Biochem. Biophys. Res. Commun. 1982, 105, 1426-1432. [CrossRef]

168. Elbein, A.D.; Rock, L.; Examiner, P.; Saucier, S.E. Inhibition of Bacterial Binding by High-Mannose Oligosacchardes. USA Patent 5,939,279, 17 August 1999.

169. Mualikrishna, G.; Tharanathan, R.N. Characterization of pectic polysaccharides from pulse husks. Food Chem. 1994, 50, 87-89. [CrossRef]

170. Thakur, B.R.; Singh, R.K.; Handa, A.K. Chemistry and uses of pectin-A review. Crit. Rev. Food Sci. Nutr. 1997, 37, 47-73. [CrossRef]

171. May, C.D. Industrial pectins: Sources, production and applications. Carbohydr. Polym. 1990, 12, 79-99. [CrossRef]

172. Morris, G.A.; Foster, T.J.; Harding, S.E. The effect of the degree of esterification on the hydrodynamic properties of citrus pectin. Food Hydrocoll. 2000, 14, 227-235. [CrossRef]

173. Mandalari, G.; Bennett, R.N.; Kirby, A.R.; Lo Curto, R.B.; Bisignano, G.; Waldron, K.W.; Faulds, C.B. Enzymatic Hydrolysis of Flavonoids and Pectic Oligosaccharides from Bergamot (Citrus bergamia Risso) Peel. J. Agric. Food Chem. 2006, 54, 8307-8313. [CrossRef]

174. Olano-Martin, E.; Mountzouris, K.C.; Gibson, G.R.; Rastall, R.A. Continuous Production of Pectic Oligosaccharides in an Enzyme Membrane Reactor. J. Food Sci. 2001, 66, 966-971. [CrossRef] 
175. Nangia-Makker, P.; Conklin, J.; Hogan, V.; Raz, A. Carbohydrate-binding proteins in cancer, and their ligands as therapeutic agents. Trends Mol. Med. 2002, 8, 187-192. [CrossRef]

176. Li, P.; Xia, J.; Nie, Z.; Shan, Y. Pectic oligosaccharides hydrolyzed from orange peel by fungal multi-enzyme complexes and their prebiotic and antibacterial potentials. LWT Food Sci. Technol. 2016, 69, 203-210. [CrossRef]

177. Ganan, M.; Collins, M.; Rastall, R.; Hotchkiss, A.T.; Chau, H.K.; Carrascosa, A.V.; Martinez-Rodriguez, A.J. Inhibition by pectic oligosaccharides of the invasion of undifferentiated and differentiated Caco-2 cells by Campylobacter jejuni. Int. J. Food Microbiol. 2010, 137, 181-185. [CrossRef] [PubMed]

178. Li, S.; Li, T.; Zhu, R.; Wang, N.; Song, Y.; Wang, S.; Guo, M. Antibacterial Action of Haw Pectic Oligosaccharides. Int. J. Food Prop. 2013, 16. [CrossRef]

179. Pristov, J.B.; Jovanović, S.V.; Mitrović, A.; Spasojević, I. UV-irradiation provokes generation of superoxide on cell wall polygalacturonic acid. Physiol. Plant. 2013, 148, 574-581. [CrossRef]

180. Tazawa, K.; Hanmyo, K.; Namikawa, H.; Mizumoto, J.; Oida, N.; Ohkami, H.; Saito, T.; Okamoto, M.; Yamashita, I.; Komatu, K.; et al. Inhibitory effects of apple pectin in colon carcinogenesis-Evaluation of the radical scavenging activity of pectic oligosaccharide. Biotherapy 1999, 13, 510-512.

181. Marx, J.L. Oxygen free radicals linked to many diseases. Science 1987, 235, 529-531. [CrossRef]

182. Zheng, R.L.; Lesko, S.A.; Ts'o, P.O. DNA damage induced in mammalian cells by active oxygen species. Sci. Sin. Ser. B Chem. Biol. Agric. Med. Earth Sci. Chung Kuo K Hsueh Yuan Chu Pan 1988, 31, 676-686.

183. Slemmer, J.E.; Shacka, J.J.; Sweeney, M.I.; Weber, J.T. Antioxidants and free radical scavengers for the treatment of stroke, traumatic brain injury and aging. Curr. Med. Chem. 2008, 15, 404-414.

184. Martinov, J.; Krstić, M.; Spasić, S.; Miletić, S.; Stefanović-Kojić, J.; Nikolić-Kokić, A.; Blagojević, D.; Spasojević, I.; Spasić, M.B. Apple pectin-derived oligosaccharides produce carbon dioxide radical anion in Fenton reaction and prevent growth of Escherichia coli and Staphylococcus aureus. Food Res. Int. 2017, 100, 132-136. [CrossRef]

185. Olano-Martin, E.; Williams, M.R.; Gibson, G.R.; Rastall, R.A. Pectins and pectic-oligosaccharides inhibit Escherichia coli O157:H7 Shiga toxin as directed towards the human colonic cell line HT29. FEMS Microbiol. Lett. 2003, 218, 101-105. [CrossRef] [PubMed]

186. Rhoades, J.; Manderson, K.; Wells, A.; Hotchkiss, A.; Gibson, G.; Formentin, K.; Beer, M.; Rastall, R.A. Oligosaccharide-Mediated Inhibition of the Adhesion of Pathogenic Escherichia coli Strains to Human Gut Epithelial Cells In Vitro. J. Food Prot. 2008, 71, 2272-2277. [CrossRef] [PubMed]

187. Guggenbichler, J.P.; De Bettignies-Dutz, A.; Meissner, P.; Schellmoser, S.; Jurenitsch, J. Acidic oligosaccharides from natural sources block adherence of Escherichia coli on uroepithelial cells. Pharm. Pharmacol. Lett. 1997, 7, 35-38.

188. Di, R.; Vakkalanka, M.S.; Onumpai, C.; Chau, H.K.; White, A.; Rastall, R.A.; Yam, K.; Hotchkiss, A.T., Jr. Pectic oligosaccharide structure-function relationships: Prebiotics, inhibitors of Escherichia coli O157:H7 adhesion and reduction of Shiga toxin cytotoxicity in HT29 cells. Food Chem. 2017, 227, 245-254. [CrossRef]

189. Lee, J.-H.; Shim, J.S.; Lee, J.S.; Kim, M.-K.; Chung, M.-S.; Kim, K.H. Pectin-like acidic polysaccharide from Panax ginseng with selective antiadhesive activity against pathogenic bacteria. Carbohydr. Res. 2006, 341, 1154-1163. [CrossRef]

190. Cohen, A.; Hannigan, G.E.; Williams, B.R.; Lingwood, C.A. Roles of globotriosyl- and galabiosylceramide in verotoxin binding and high affinity interferon receptor. J. Biol. Chem. 1987, 262, 17088-17091.

191. Lingwood, C.A.; Law, H.; Richardson, S.; Petric, M.; Brunton, J.L.; De Grandis, S.; Karmali, M. Glycolipid binding of purified and recombinant Escherichia coli produced verotoxin in vitro. J. Biol. Chem. 1987, 262, 8834-8839.

192. Bergan, J.; Dyve Lingelem, A.B.; Simm, R.; Skotland, T.; Sandvig, K. Shiga toxins. Toxicon 2012, 60, $1085-1107$. [CrossRef]

193. Melton-Celsa, A.R. Shiga Toxin (Stx) Classification, Structure, and Function. Microbiol. Spectr. $2014,2$. [CrossRef]

194. Keusch, G.T.; Jacewicz, M.; Mobassaleh, M.; Donohue-Rolfe, A. Shiga Toxin: Intestinal Cell Receptors and Pathophysiology of Enterotoxic Effects. Rev. Infect. Dis. 1991, 13, S304-S310. [CrossRef]

195. Acheson, D.W.; Moore, R.; De Breucker, S.; Lincicome, L.; Jacewicz, M.; Skutelsky, E.; Keusch, G.T. Translocation of Shiga toxin across polarized intestinal cells in tissue culture. Infect. Immun. 1996, 64, 3294-3300. [CrossRef] [PubMed] 
196. Li, Z.; Feizi, T. The neoglycolipid (NGL) technology-based microarrays and future prospects. FEBS Lett. 2018, 592, 3976-3991. [CrossRef] [PubMed]

197. Li, Z.; Chai, W. Mucin O-glycan microarrays. Curr. Opin. Struct. Biol. 2019, 56, 187-197. [CrossRef] [PubMed]

(C) 2020 by the authors. Licensee MDPI, Basel, Switzerland. This article is an open access article distributed under the terms and conditions of the Creative Commons Attribution (CC BY) license (http://creativecommons.org/licenses/by/4.0/). 